Commodity Price Volatility and the Sources of Growth

Tiago V. de V. Cavalcanti, Kamiar Mohaddes and Mehdi Raissi

17 January 2011

CWPE 1112 


\title{
Commodity Price Volatility and the Sources of Growth*
}

\author{
Tiago V. de V. Cavalcanti, Kamiar Mohaddes ${ }^{\dagger}$, and Mehdi Raissi \\ Faculty of Economics, University of Cambridge
}

January 17, 2011

\begin{abstract}
This paper studies the impact of the level and volatility of commodity terms of trade on economic growth, as well as on the three main growth channels: total factor productivity, physical capital accumulation, and human capital acquisition. We argue that volatility, rather than abundance per se, drives the "resource curse" paradox and also investigate empirically whether export diversification of commodity dependent countries contribute to faster growth. We use the standard system GMM approach as well as an augmented version of the pooled mean group (PMG) methodology of Pesaran et al. (1999) for estimation. The latter takes account of cross-country heterogeneity and cross-sectional dependence, while the former controls for biases associated with simultaneity and unobserved country-specific effects. Using both annual data for 19702007 and five-year non-overlapping observations, we find that while commodity terms of trade growth enhances real output per capita, volatility exerts a negative impact on economic growth operating mainly through lower accumulation of physical capital. Our results indicate that the negative growth effects of CTOT volatility offset the positive impact of commodity booms.
\end{abstract}

JEL Classifications: C23, F43, O13, O40.

Keywords: Growth, resource curse, commodity prices, volatility.

\footnotetext{
${ }^{*}$ We are grateful to Hashem Pesaran, seminar participants at the CSAE University of Oxford and the MCD Discussion Forum Series at the IMF, as well as conference participants at the ERF Regional Conference on Environmental Challenges in the MENA Region for constructive comments and suggestions. Financial support from the Economic Research Forum (ERF) through the 'Second Environmental Economics Research Competition for MENA' is gratefully acknowledged. The views expressed herein are those of the authors and do not necessarily represent the views of the ERF.

${ }^{\dagger}$ Corresponding author. Email address: km418@cam.ac.uk.
} 


\section{Introduction}

Many countries in the world specialize in the export of just a few primary products and/or depend heavily on natural resource endowments. These countries are usually exposed to substantial commodity price volatility and suffer from a high degree of macroeconomic instability, which in turn might have negative implications for their GDP per capita growth. While most studies on the so called "resource curse" paradox look at the negative growth effects of commodity dependence in levels, they, with a few exceptions, overlook the volatility channel of impact. The central message of this paper is that the volatility of commodity prices and export revenues should be considered in the growth analysis alongside levels. This is particularly important for primary product dependant countries as the source of the resource curse seems to be the volatility in commodity prices as opposed to the abundance of the resource itself.

Methodologically, we employ two econometric techniques: (1) a system GMM approach (a homogeneous panel) and (2) an augmented version of the Pooled Mean Group (PMG) estimator (a heterogenous panel). The former corrects for biases associated with the joint endogeneity of the explanatory variables in dynamic panel data models and the problems induced by unobserved country specific effects while the latter takes account of cross-country heterogeneity and cross-sectional dependence. We obtain annual data for the period 19702007 and construct a panel dataset of 118 countries. We use the annual observations for the PMG approach to fully exploit the time series dimension of the data, but we transform our time series data into at most seven non-overlapping five-year observations for the GMM estimation. This is a standard procedure in the empirical literature of growth with panel data, to abstract from business cycles effects, see Aghion et al. (2009). Moreover, we make use of a country-specific commodity-price index that depends on the composition of a particular country's commodity export and import baskets and investigate the impacts on growth of commodity terms of trade (CTOT) level and volatility.

We expect volatility to have a negative growth effect in just primary commodity dependent countries and as such split our sample into two sets: $(i) 62$ primary commodity exporters, and (ii) remaining 56 countries which have a more diversified export basket. The estimation results confirm our prior expectations as in both the full sample, 118 countries, and the second subsample, $(i i)$, we observe that volatility is insignificantly related to output per capita growth. This is in contrast to the experience of the 62 primary product exporters, $(i)$, for whom our results indicate that lower volatility of CTOT contribute to enhanced growth. We attribute this asymmetric pattern to the export sophistication of the latter group, $(\mathrm{ii})$. Countries with a diversified basket of exports, especially manufacturing or service-sector goods, can be expected to grow faster and be better insured against price fluctuations in individual commodities. This analysis is in line with what is being argued in Hausmann et al. (2007) among others.

Furthermore, having identified a negative impact of volatility on growth in natural resource dependant countries, we examine the channels through which this effect operates, notably physical and human capital accumulation, and total factor productivity (TFP). We find that CTOT volatility is associated with lower accumulation of both human and physical capital and hence through that lower growth. However, we cannot find a significantly neg-

ative association between volatility and total factor productivity growth which rejects the 
hypothesis that commodity and natural resource dependent countries have fewer possibilities for technological progress. This finding is important as the behavior of an economy experiencing a boom differs significantly from the standard Dutch disease model in the presence of a sufficiently dynamic and knowledge-intensive natural resource sector.

Finally, while the resource curse hypothesis predicts a negative effect of commodity booms on growth, our empirical findings (in line with recent estimates) show quite the contrary: higher level of commodity terms of trade significantly raises growth. Therefore, we argue that volatility, rather than abundance per se, drives the "resource curse" paradox. Indeed our results confirm that the negative growth effects of CTOT volatility offset the positive impact of CTOT growth on real GDP per capita.

The rest of the paper is set out as follows: Section 2 gives a brief review of the relevant literature while Section 3 describes the data used in our analysis. In Section 4 we transform our annual data to five-year non-overlapping averages and employ the system GMM methodology to see the effects of CTOT growth and volatility on real output per capita growth as well as its sources. In Section 5 we make use of annual data and the crosssectionally augmented Pooled Mean Group (PMG) estimator, which explicitly takes into account cross-country heterogeneity, to see whether the GMM results are maintained in this setting. Section 6 discusses the policy implications of our findings and, finally, Section 7 offers some concluding remarks.

\section{Literature Review}

We are not the first ones to emphasize the importance of volatility for economic growth. Following the influential work of Ramey and Ramey (1995), the consequences of excess volatility for long-run growth have attracted some attention in both the empirical and theoretical literature. Blattman et al. (2007) investigate the impact of terms of trade volatility, arising from excessive commodity price fluctuations, on growth performance of a panel of 35 commodity dependent countries between 1870 and 1939. They provide evidence of the adverse effects of volatility on foreign investment and through that on economic growth in what they call "periphery" nations. Aghion et al. (2009), using a system GMM dynamic panel data method for 83 countries over the period 1960-2000, show that higher levels of exchange rate volatility can stunt growth, especially in countries with thin capital markets. Bleaney and Greenaway (2001) estimate a panel data model for a sample of 14 sub-Saharan African countries over 1980-1995 and show that growth is negatively affected by terms of trade volatility, and investment by real exchange rate instability.

Most closely related in motivation to our paper is van der Ploeg and Poelhekke (2009) and van der Ploeg and Poelhekke (2010) who find that the volatility of unanticipated GDP per capita growth has a significant negative impact on growth, but the effect depends on a country's level of financial development. Our paper differs from theirs in many dimensions: first, we investigate the effects of CTOT volatility instead of the volatility of unanticipated GDP on economic growth. Our econometric methodologies are also different from theirs, since they use Maximum Likelihood fixed effects panel techniques, while we use GMM and PMG approaches. Interestingly, our results are quite similar in terms of how volatility affects growth. Lastly, but not least, we also explore the different channels to which CTOT volatility 
affects economic growth, while they concentrate on the overall effect.

This paper is also related to a growing strand of literature on and interest in the resource curse paradox, following Sachs and Warner (1995). ${ }^{1}$ The empirical evidence on the resource curse paradox is mixed, with some confirming Sachs and Warner's results of the negative effect of the level of resource abundance on economic growth, see Rodriguez and Sachs (1999), Gylfason et al. (1999), and Bulte et al. (2005) among others. But there is a growing number of papers providing evidence against the conventional resource curse paradox. For instance, Cavalcanti et al. (2009), using a heterogenous cointegrated panel data method for 53 oil and gas producing countries, show that natural resource abundance per se is not a determinant of growth failure. The positive effect of resource abundance on both development and growth is also supported by Esfahani et al. (2009), who develop a long run growth model for a major oil exporting economy and derive conditions under which oil revenues are likely to have a lasting impact. Another empirical challenge to this paradox comes from Brunnschweiler and Bulte (2008), who argue that the so-called resource curse does not exist when one uses the correct measure of resource abundance in regressions. Moreover, Alexeev and Conrad (2009) show that allowing for some important omitted variables, the unconditional version of the resource curse hypothesis falls apart. Finally, using more disaggregated data, Stijns (2005) finds no correlation of fuel and mineral reserves with growth between 1970 and 1989.

Another related branch of the literature investigates the channels through which natural resource abundance affects economic growth negatively. Gylfason (2001), for instance, shows that natural resource abundance appears to crowd out human capital investment with negative effects on the pace of economic activity, while Bravo-Ortega et al. (2005) show that higher education levels can in fact offset the negative effects of resource abundance. A number of papers, such as Papyrakis and Gerlagh (2004) and Gylfason and Zoega (2006), also focus on the physical capital accumulation channel and argue that resource abundance leads to lower investment in physical capital which then dampens GDP growth. However, all these studies focus on the effect of the level of resource abundance on economic growth (and its sources) and as such they do not investigate whether there are any adverse effects of the volatility in commodity prices or resource income on growth.

\section{Data}

To empirically test the relationship between real GDP per capita growth and commodity terms of trade (CTOT) level and volatility, we obtain annual data from 1970 to 2007 on real GDP per capita, a CTOT index which is based on the prices of 32 primary commodities, ${ }^{2}$ as well as other important determinants of growth: trade openness, government burden, lack of price stability, and human capital. Since we are also interested in testing whether or not export diversification enhances growth in the countries in our sample, we make use of a measure of export sophistication developed by Hausmann et al. (2007) in our regressions.

\footnotetext{
${ }^{1}$ See also Rosser (2006) and van der Ploeg and Venables (2009) for an extensive survey of the resource curse paradox.

${ }^{2}$ The commodities are: Shrimp, beef, lamb, wheat, rice, corn, bananas, sugar, coffee, cocoa, tea, soybean meal, fish meal, hides, soybeans, natural rubber, hardlog, cotton, wool, iron ore, copper, nickel, aluminum, lead, zinc, tin, soy oil, sunflower oil, palm oil, coconut oil, gold, and crude oil.
} 
This index can be seen to measure the benefits of diversifying the economy away from primary products to productivity enhancing goods. For details on the calculation and construction of these variables and sources of the data used see Table 2.

While this paper initially investigates the growth effects of CTOT level and volatility for the whole sample of 118 countries, it also tests whether this relationship is dependant on a country being a primary commodity exporter. As such, we split our sample into two subsets with the first one consisting of 62 primary commodity exporting countries, defining them as those for whom the ratio of primary commodities to total exports exceeds 50 percent. $^{3}$ The second subsample consists of the remaining 56 countries, which have a more diversified export structure. For a complete list of all the countries see Table 1.

\subsection{Commodity Terms of Trade}

Our country specific measure for the CTOT index is from Spatafora and Tytell (2009) and is defined as:

$$
C T O T_{i t}=\prod_{j}\left(\frac{P_{j t}}{M U V_{t}}\right)^{X_{i j}} / \prod_{j}\left(\frac{P_{j t}}{M U V_{t}}\right)^{M_{i j}},
$$

where $M U V_{t}$ is a manufacturing unit value index used as a deflator, $X_{i j}\left(M_{i j}\right)$ is the share of exports (imports) of commodity $j$ in country $i$ 's GDP, and $P_{j t}$ is the individual commodity price. ${ }^{4}$ By construction the movements in the CTOT are due to changes in commodity prices as the export and import shares are time-averaged and therefore remain constant over time. The advantage of (1) over a simple commodity price index is that it allows countries to be influenced by changes in commodity prices differently, depending on the composition of their export and import baskets. The CTOT index is used to construct two important variables. The first one is a commodity terms of trade growth series, a proxy for resource abundance, calculated as the annual log differences in the CTOT index and the second is a measure of CTOT volatility explained in more detail below.

Resource revenue (or rent), being calculated as the production multiplied by price (minus marginal cost), has been used extensively in a number of recent studies in the resource curse literature as a measure of abundance. Given that production levels do not change much over time and are generally persistent, most changes in resource rents or revenues in the short-run (for instance five-years) are due to price fluctuations. Moreover, the Dutch disease phenomenon focuses on the changes in natural resource prices as the main driver of the eventual drag on TFP and output growth. Therefore, the commodity terms of trade growth considered in this paper, which is a weighted measure of changes in commodity prices, can be seen as a proxy for resource abundance.

In contrast to most studies in the growth literature which employ time-invariant variables, including van der Ploeg and Poelhekke (2009) and van der Ploeg and Poelhekke (2010), we construct two time-variant measures of CTOT volatility. First we consider the five year nonoverlapping standard deviation of annual log differences in the commodity terms of trade

\footnotetext{
${ }^{3}$ This ratio is calculated based on data from the United Nations Conference on Trade and Development online database using SITC 0, 1, 2, 3, 4, 68, 667, and 971.

${ }^{4} \mathrm{~A}$ similar measure is also used by Lee et al. (2008).
} 
index:

$$
\sigma_{i, t, t+5}=\operatorname{stdev}\left[\ln \left(C T O T_{i t}\right)-\ln \left(C T O T_{i t-1}\right)\right],
$$

which indicates the extent to which CTOT growth deviates from a given mean at any point in time. Second, as annual data on CTOT volatility is required in the pooled mean group (PMG) regressions, we estimate a generalized autoregressive conditional heteroscedasticity. $(\mathrm{GARCH})$ model using the logarithm of $C T O T_{i t}$. This approach estimates the "conditional variance" of the logarithm of the CTOT for each year, independent of other observations. The retrieved variance series might yield periods with different volatility levels and therefore a time varying measure. More specifically, we estimate the volatility of the commodity terms of trade from a $\operatorname{GARCH}(1,1)$ model using a regression of a change in the logarithm of the variable on a constant (this formulation is used to avoid prejudging the issue of stationarity) as in Bleaney and Greenaway (2001) and Serven (2003):

$$
\begin{aligned}
\ln C T O T_{i t}-\ln C T O T_{i t-1} & =\kappa_{0}+\xi_{i t} \\
\sigma_{i t}^{2} & =\lambda_{0}+\lambda_{1} \xi_{i t-1}^{2}+\lambda_{2} \sigma_{i t-1}^{2}
\end{aligned}
$$

where $\xi_{i t} \sim N\left(0, \sigma_{i t}^{2}\right), \xi_{i t-1}^{2}$ is the squared residuals, $\sigma_{i t}^{2}$ is the conditional variance of the regression disturbances, $\lambda_{0}$ and $\lambda_{1}$ are the ARCH parameters, and $\lambda_{2}$ is the GARCH parameter. We calculate CTOT volatility as the square root of $\sigma_{i t}^{2}$.

The upper graphs in Figure 1 illustrate a simple bivariate relationship between GDP per capita growth and CTOT growth over the entire period 1970-2007, suggesting a mild positive correlation between these two variables for either of our two subsamples. Examining the two lower graphs, we observe that while higher CTOT volatility is associated with lower GDP growth in primary commodity exporting countries, this relationship does not hold for the other subsample, which has a more diversified export structure. Overall, the results from Figure 1 represent preliminary evidence that while commodity booms are not determinants of economic failure (contrary to the resource curse hypothesis), the volatility of CTOT stunts output growth only for countries that are dependant on the export of primary commodities. This is perhaps not surprising as those countries with a diversified basket of exports, especially manufacturing or service-sector goods, can be expected to grow faster and be better insured against price fluctuations in individual commodities.

In Section 4 we will add a whole range of control variables and deal with possible endogeneity problems through a system GMM multivariate treatment to investigate whether the above results survive for the full sample and the two subsamples, as suggested by Figure 1. We will also investigate the relationship between resource abundance and CTOT volatility with that of output growth using annual data and applying an augmented version of the Pooled Mean Group (PMG) methodology in Section 5. Since we also would like to investigate possible mechanisms through which CTOT volatility can harm economic growth, we focus on three channels which have been widely discussed in the literature: (i) TFP growth, (ii) physical- and (iii) human capital accumulation. To do this analysis, we need to construct series for physical and human capital stocks as well as for TFP. In what follows we briefly describe how these series were constructed. 


\subsection{Physical Capital Accumulation}

We apply the perpetual inventory method of Hall and Jones (1999) to data from the Penn World Tables (PWT) 6.3, see Heston et al. (2009), to retrieve the series of the physical capital stock, $K$. We construct the initial stock of capital, $K_{i t_{0}}$, for country $i$ as:

$$
K_{i t_{0}}=\frac{I_{i t_{0}}}{g_{I}+\delta},
$$

where $I_{i t}$ represents investment and is defined as:

$$
I_{i t}=k i_{i t} \times r g d p c h_{i t} \times p o p_{i t},
$$

in which $k i_{i t}$ measures the investment share of real GDP per capita $\left(r g d p c h_{i t}\right)$, pop $p_{i t}$ is population, and $g_{I}$ is the geometric average growth rate of $I_{i t}$ between $t_{0}$ and $t_{0}+10$. Since we have access to data on investment from 1960 for most countries, we set $t_{0}$ to this year. ${ }^{5}$ Furthermore, we assume a depreciation rate, $\delta$, of six percent and compute the subsequent values of the capital stock as:

$$
K_{i t}=(1-\delta) K_{i t-1}+I_{i t} .
$$

\subsection{Human Capital Stock}

To calculate the level of human capital stock in country $i$, we obtain data on the average years of schooling attained (total, primary, secondary, tertiary) in five year intervals from the Barro and Lee Educational Attainment Dataset 2010. Since annual data is required to retrieve the human capital series, we interpolate the Barro and Lee (2010) dataset. Moreover, we assume that labor is homogeneous within a country and that each unit of labor has $s_{i t}$ years of schooling (education). Therefore the labor-augmenting human capital is given by:

$$
H_{i t}=e^{\psi\left(s_{i t}\right)} .
$$

Following Psacharopoulos (1999), ${ }^{6}$ we specify $\psi\left(s_{i t}\right)$ as a piecewise linear function with coefficients (returns to schooling) 0.134 for the first four years of education, 0.101 for the next four years, and 0.068 for any value of $s_{i t}>8 .^{7}$

\subsection{Productivity}

In constructing the total factor productivity series we follow Hall and Jones (1999) and assume that output $Y_{i}$ in country $i$ is produced according to the following constant returns to scale production function:

$$
Y_{i t}=K_{i t}^{\alpha}\left(A_{i t} H_{i t} L_{i t}\right)^{1-\alpha},
$$

\footnotetext{
${ }^{5}$ In those countries for which data on investment is missing in $1960, t_{0}$ is the next available data point followed by other observations.

${ }^{6}$ See also Psacharopoulos and Patrinos (2004).

${ }^{7}$ We also constructed the human capital series by assuming that the returns to primary, secondary, and tertiary schooling is equal to $0.134,0.101$, and 0.068 per annum, but as expected this does not lead to any significant change in the series or the results.
} 
where $K_{i t}$ denotes the stock of physical capital defined in (6), $A_{i t}$ is a labor-augmenting productivity factor, $H_{i t}$ is a measure of the average human capital of workers defined in (7), and $L_{i t}$ is labor input in use:

$$
L_{i t}=\frac{r g d p c h_{i t} \times p o p_{i t}}{r g d p w o k_{i t}}
$$

where as before rgdpch $_{i t}$ is real GDP per capita, pop $_{i t}$ is a measure of population and rgdpwok $k_{i t}$ is real GDP per worker from the PWT 6.3. The capital share, $\alpha$, is assumed constant across countries and set equal to $1 / 3$.

Finally, using the data on output per worker, capital, population, and schooling, we can construct the level of total factor productivity as follows:

$$
A_{i t}=\frac{Y_{i t}}{H_{i t} L_{i t}}\left(\frac{K_{i t}}{L_{i t}}\right)^{-\frac{\alpha}{1-\alpha}} .
$$

\section{Analysis Using Five-year Averages}

This Section briefly reviews the GMM methodology employed and presents the estimation results of the effects of (i) commodity terms of trade growth, (ii) its volatility, (iii) an export sophistication measure, and (iv) a conditioning information set on growth and its sources.

\subsection{GMM Methodology}

We begin with a basic specification that can nest much of the existing work on the empirics of economic growth:

$$
g_{y, i t}=(\delta-1) \ln y_{i t-1}+\gamma^{\prime} X_{i t}+\beta^{\prime} Z_{i t}+\mu_{t}+\eta_{i}+\varepsilon_{i t},
$$

where $g_{y, i t}$ is the geometric average growth rate of real GDP per capita between $t$ and $t+\tau$; $y_{i t-1}$ is real GDP per capita at the beginning of each period; $Z_{i t}$ is a set of other control variables; and $X_{i t}$ are the particular variables of interest. $\mu_{t}$ is the time-specific effect; $\eta_{i}$ is the country-specific effect; and $\varepsilon_{i, t}$ is the error term.

Much of the empirical growth literature is based on estimations of an equation similar to (11) using a cross-sectional approach, but the drawbacks of this method are well known. Cross-sectional regressions clearly suffer from endogeneity problems as by construction, the initial level of income, $y_{i t-1}$, is correlated with the growth variable, $g_{y, i t}$. This endogeneity bias is larger when considering the simultaneous determination of virtually all growth determinants. Furthermore, substantial bias may be induced by the correlation of unobserved country-specific factors and the explanatory variables.

Traditional panel data estimators such as fixed and random effects are not consistent in the present context either, due to the inclusion of lagged dependent variables in our regressions (e.g. the initial level of GDP per capita). More specifically, the fixed effects estimator is inconsistent because it usually eliminates $\eta_{i}$ by a de-meaning transformation that induces a negative correlation between the transformed error and the lagged dependent variables of order $1 / T$, which in short panels remains substantial. The assumption of a lack of correlation between $\eta_{i}$ and the explanatory variables required for random effects consistency 
is also violated as both $g_{y, i t}$ and $y_{i t-1}$ are functions of $\eta_{i}$. Furthermore, these estimators will be inconsistent if the errors show either heteroscedasticity or serial correlation.

To correct for the biases created by lagged endogenous variables and the simultaneity of growth determinants, we use the generalized-method-of-moments (GMM) estimators developed for dynamic panel data models. Following Anderson and Hsiao (1982), and Arellano and Bond (1991), we take first-differences of equation (11) to eliminate the unobserved country fixed effects, $\eta_{i}$, yielding:

$$
\Delta g_{y, i t}=(\delta-1) \Delta y_{i t-1}+\gamma^{\prime} \Delta X_{i t}+\beta^{\prime} \Delta Z_{i t}+\Delta \mu_{t}+\Delta \varepsilon_{i t} .
$$

The first-difference of equation (11) gives the transformed error a moving-average, $M A(n)$, structure that is correlated with the differenced lagged dependent variable. Assuming that the error term, $\varepsilon_{i t}$, is not serially correlated and that the explanatory variables $Z_{i t}$ are weakly exogenous, ${ }^{8}$ the difference GMM estimator uses the following moment conditions:

$$
\begin{array}{ll}
E\left(y_{i t-s}, \Delta \varepsilon_{i, t}\right)=0 & \text { for } s \geq 2 \text { and } t=3, \ldots T, \\
E\left(Z_{i t-s}, \Delta \varepsilon_{i, t}\right)=0 & \text { for } s \geq 2 \text { and } t=3, \ldots T .
\end{array}
$$

However, in growth regressions where the explanatory variables are persistent over time, lagged levels are often weak instruments for difference equations. ${ }^{9}$ To reduce the potential biases and imprecision associated with the GMM difference estimator, we follow Levine et al. (2000) and Aghion et al. (2009) among others in employing a system estimator that also includes equation (11) in levels, with the lagged differences of the endogenous variables as instruments (see Arellano and Bover (1995) and Blundell and Bond (1998)). These are appropriate instruments under the assumption that there is no correlation between the differences of the variables and the country-specific effects. Therefore the additional moment conditions for the regression in levels are:

$$
\begin{array}{ll}
E\left(\Delta y_{i t-s}, \eta_{i}+\varepsilon_{i, t}\right)=0 & \text { for } s=1, \\
E\left(\Delta Z_{i t-s}, \eta_{i}+\varepsilon_{i, t}\right)=0 & \text { for } s=1 .
\end{array}
$$

The moment conditions effectively give us $T-1$ equations in first differences followed by $T$ equations in levels. The solutions to these equations are then weighted by the inverse of a consistent estimate of the moment condition covariance matrix in a two-step method. To test the validity of the instruments and therefore consistency of the GMM estimator, we consider two specification tests suggested by Arellano and Bond (1991), Arellano and Bover (1995), and Blundell and Bond (1998). The first is a Hansen test of over-identifying restrictions, which tests the overall validity of the instruments and the second test examines the hypothesis that the error term $\varepsilon_{i, t}$ is not serially correlated. ${ }^{10}$ Finally, we compute robust two-step standard errors following the methodology suggested by Windmeijer (2005) to correct for small sample biases.

\footnotetext{
${ }^{8}$ The explanatory variables are assumed to be uncorrelated with future realizations of the error term.

${ }^{9}$ For further details see Alonso-Borrego and Arellano (1999) and Blundell and Bond (1998).

${ }^{10}$ We test whether the differenced error term is second-order serially correlated as by construction, it is most likely first-order serially correlated even if the original error term is not.
} 


\subsection{Empirical Results}

To filter out business cycle fluctuations and to focus on the long-run effects of CTOT growth and volatility, we follow the literature in transforming our annual series into non-overlapping five-year averages. Given that we have access to annual data from 1970 to 2007, we can construct an unbalanced panel with a maximum of seven observations per country covering the period 1970 to 2005.

\subsubsection{Volatility and Growth}

We propose to use the system GMM estimator described above, but as the two-step standard errors on estimated coefficients will be biased downward in small samples like ours, we make use of Windmeijer (2005) approach to correct for that bias. The following equation is estimated:

$$
\begin{aligned}
g_{y, i t}= & (\delta-1) \ln y_{i t-1}+\gamma_{1} g_{C T O T, i t}+\gamma_{2} \sigma_{C T O T, i t} \\
& +\gamma_{3} E X P Y_{i t}+\beta^{\prime} Z_{i t}+\mu_{t}+\eta_{i}+\varepsilon_{i t},
\end{aligned}
$$

where $g_{y, i t}$ is the geometric average growth rate of real GDP per capita between $t$ and $t+\tau$; $y_{i t-1}$ is real GDP per capita at the beginning of each period; $g_{C T O T, i t}$ is the growth rate of the CTOT index; and $\sigma_{C T O T, i t}$ is its volatility. EXPY $Y_{i t}$ is a measure of export sophistication and $Z_{i t}$ is a set of other control variables now standard in the growth literature ${ }^{11}$ including education, trade openness, government burden, and lack of price stability. $\mu_{t}$ is the timespecific effect; $\eta_{i}$ is the country-specific effect; and $\varepsilon_{i t}$ is the error term.

Table 3 presents the estimation results of the impact of commodity terms of trade growth and volatility as well as export diversification on GDP per capita growth. In the first regression using the whole sample of 118 countries, [1.1], we observe that an increase in $g_{\text {CTOT }}$ is both growth enhancing and highly significant. On the other hand, although the coefficient of CTOT volatility is negative, this is in fact insignificant and thus there is no evidence that volatility in commodity prices harms growth for the full sample. As already discussed in section 3.1, we expect the growth experience of primary commodity exporters to be different from those countries that are not dependant on a handful of primary products, see Figure 1, and therefore we split the sample into two subsets.

Regression [1.2] shows the opposite significant effects of $g_{C T O T}$ and $\sigma_{C T O T}$ on GDP growth for the 62 primary commodity exporting countries in our sample. While commodity price booms significantly increase economic growth, volatility affects it negatively. The positive growth effect of $g_{C T O T}$ provides evidence against the traditional resource curse hypothesis, which argues that it is the level of resource abundance that affects economic growth negatively. Our findings are supported by a number of recent studies in the literature such as Brunnschweiler and Bulte (2008), Cavalcanti et al. (2009), Cavalcanti et al. (2010), and van der Ploeg and Poelhekke (2010). The negative relationship between volatility and growth in resource dependant countries is also documented in van der Ploeg and Poelhekke (2009) and van der Ploeg and Poelhekke (2010), who acknowledge that the source of the

\footnotetext{
${ }^{11}$ See, for instance, Levine et al. (2000) and Aghion et al. (2009).
} 
resource curse is the volatility in commodity prices as opposed to resource abundance, although their empirical analysis is based on the volatility of unanticipated output growth and not of commodity prices.

These results, however, do not hold for the second subsample including the remaining 56 countries, see regression [1.3]. For net commodity importing countries, which are by definition not resource abundant, changes in commodity prices (or their volatility) are not expected to have any major impact on physical and human capital investment or the TFP growth rate. Consequently, there should be no significant effect on economic growth stemming from CTOT growth or its volatility. In addition, these countries generally have highly diversified export and import baskets, implying that the changes in commodity prices should have a significantly lower effect on them as opposed to primary commodity dependant countries. This arguments is also supported by observing that the coefficient of export sophistication variable, $E X P Y_{i t}$, is significant and positive in all three regressions in Table 3. This suggests that diversifying away from exporting only a handful of primary commodities towards technology improving exports can significantly increase the growth rate of an economy.

Note that in all three regressions, the control variables have the expected signs and are all significant except for education in all regressions and government burden in [1.3] . Overall, while higher level of trade openness is growth enhancing, price instability and government burden stunt GDP growth. In addition, there is evidence of income convergence across countries with the coefficient on the lagged dependent variable being significant for the full sample and the sample consisting of net primary commodity importers. However, this finding should be interpreted with caution as there is a large cross country heterogeneity in our sample of 118 countries which might render the estimated coefficient on $\ln y_{i t-1}$ biased. Finally, in all regressions, the Hansen and second order serial correlation test statistics, which examine the validity of internal instruments used, are well above the conventional significance levels.

\subsubsection{Volatility and the Channels to Economic Growth}

To determine the channel(s) through which GDP per capita growth is negatively affected by CTOT volatility in the subsample of 62 commodity exporters, we follow Beck et al. (2000) in investigating three possible sources which are widely acknowledged elsewhere in the literature: TFP, human and physical capital investment. The importance of these channels and the reasons for why they might be the means by which growth is dampened in resource dependant countries is discussed extensively in Gylfason (2006). As before, we use the GMM dynamic panel data approach to estimate the following equation:

$$
\begin{aligned}
g_{w, i t} & =(\delta-1) \ln w_{i t-1}+\gamma_{1} g_{C T O T, i t}+\gamma_{2} \sigma_{C T O T, i t} \\
& +\gamma_{3} E X P Y_{i t}+\beta^{\prime} Z_{i t}+\mu_{t}+\eta_{i}+\varepsilon_{i t}
\end{aligned}
$$

where $w=\{\mathrm{TFP}$, or physical capital per capita, or human capital per capita $\}$; $g_{w, i t}$ is the geometric average growth rate of $w$ between dates $t$ and $t+\tau$; and $w_{i t-1}$ is the value of $w$ at the beginning of each period. All other variables are as defined in equation (13).

Not surprisingly, looking at regression [2.1] in Table 4, we observe that human capital enhances TFP and so does export diversification. However, the channel through which CTOT 
affects growth is clearly not total factor productivity as the growth rate and the volatility of CTOT are both insignificant in the TFP regression. This suggests that commodity price booms or CTOT volatility do not have an adverse impact on TFP growth. This finding contradicts the Dutch disease hypothesis, ${ }^{12}$ which predicts that an increase in commodity prices will lead to real exchange rate appreciation and through that a fall in output in the non-resource and more dynamic traded goods sector, and in turn leads to a reduction of TFP growth and eventually the GDP growth rate. This effect would most likely be present if the revenues from primary commodities were to be intrinsically temporary, like in the Netherlands in the 1960's, but this is not the case for most of the countries in our sample, which have remained exporters of (a few) primary products for decades. For instance, Iran has been a major crude oil exploiter and producer for over a century and with the current reserve to extraction ratio, is predicted to remain so for many decades. ${ }^{13}$ Thus an increase in the price of primary commodities, or its volatility, does not necessarily have negative long run effects on TFP in these countries, as their economies would re-adjust after a shock in the price of primary commodities. This is the case unless there are important non-convexities in the economy, but this seems not to be supported by the econometric evidence given that an increase in commodity prices or volatility has no significant effect on TFP growth in the long run, see regression [2.1].

In contrast, regression [2.2] shows that both commodity terms of trade growth and volatility have significant impacts on physical capital accumulation for primary commodity dependant countries. While a commodity price boom increases the physical capital stock, higher volatility of commodity prices significantly reduces it. Therefore, capital accumulation seems to be an important channel through which volatility affects GDP per capita growth. This result is in line with what is argued in Papyrakis and Gerlagh (2004), Gylfason and Zoega (2006) and Esfahani et al. (2009) among others. A possible explanation for this finding is that people save less in commodity dependant countries as they perceive the revenues from primary commodity exports a continuous stream of future wealth. Another possibility is that the uncertainty arising from commodity price volatility in these economies might suppress the accumulation of physical capital by risk averse investors.

The estimation results from [2.3] are similar to that of regression [2.2]. They indicate that human capital accumulation is another channel through which volatility harms growth. A possible explanation for this finding is that uncertainty generally increases income inequality and leads to binding credit constraints on households with low net worth. But given that people finance their own education, higher volatility then leads to a reduction in human capital investment and thus lowers economic growth. This reduction in the growth rate of an economy due to the crowding out of human capital investment in resource dependant and/or volatile economies is also what is found in the literature: Gylfason (2001), Birdsall et al. (2001), Papyrakis and Gerlagh (2004), Aizenman and Pinto (2005), and Gylfason and Zoega (2006).

Moreover, while export sophistication leads to higher investment in physical capital, see regression [2.2], this effect is absent in the human capital accumulation equation, [2.3].

\footnotetext{
${ }^{12}$ See, for example, Corden and Neary (1982), Krugman (1987), and Neary and van Wijnbergen (1986) among others.

${ }^{13}$ For more details see Esfahani et al. (2009).
} 
This result seems to suggest that for commodity dependent countries, diversification is an important mechanism that offsets the reduction in physical capital accumulation (brought about by large primary commodity export revenues) with an increase in productivity.

Furthermore, the coefficients of the control variables in all three regressions in Table 4 generally have the expected signs, with those that are unexpected being insignificant. As before, the Hansen and second order serial correlation test statistics in the three regressions are all well above the conventional significance levels confirming the validity of internal instruments and the lack of second order serial correlation in the error terms.

We also estimated regressions [2.1] to [2.3] for the 56 net commodity importing countries in our sample and as expected found no significant effect of $g_{C T O T}$ and $\sigma_{C T O T}$ on the three channels of growth described above for these countries. This is consistent with our findings in regression [1.3] in which the growth rate and the volatility of the commodity terms of trade had no significant effect on GDP growth for the 56 countries. Given that these countries are not primary commodity dependant and have highly diversified import and export baskets we argue that this is in fact what should be expected. These results are not reported but they available upon request.

\subsubsection{Robustness Checks}

In order to make sure that our results are not driven by the way in which commodity terms of trade volatility is measured, instead of using five year non-overlapping standard deviation of CTOT growth, we estimate the conditional volatility of the commodity terms of trade from a GARCH(1,1) model and use it as our alternative measure of instability, see Section 3.1 for more details. The results in Table 5 echo those in Table 3. While the coefficient of CTOT volatility is negative for the full sample and for the 56 net commodity importing countries, see regressions [3.1] and [3.3], they are in fact insignificant. In contrast, regression [3.2] shows that CTOT volatility has a significantly negative effect on GDP growth for primary commodity exporting countries. Note also that in contrast to the predictions of the resource curse hypothesis, a higher growth rate of commodity prices enhances real output per capita growth significantly for both the full sample and for the 62 primary commodity exporters. This finding is consistent with the one obtained in regressions [1.1] and [1.2] and with the evidence that is provided in the recent literature on the resource curse hypothesis. However, the impact of CTOT growth on GDP per capita is smaller than that of CTOT volatility as shown in Table 5.

Having established a negative association between the $\operatorname{GARCH}(1,1)$ measure of CTOT volatility and economic growth, we investigate the three potential channels through which this effect operates. Note that TFP is not one of these channels as neither CTOT growth nor volatility has any significant effect on technological growth, see regression [4.1] in Table 6. This is in line with the results from regression [2.1] and provides further evidence against the Dutch disease operating in the primary commodity dependant countries in our sample.

In addition, although the coefficient of $\sigma_{C T O T}$ is negative in regression [4.3] it is in fact insignificant and as such there is no evidence that CTOT volatility crowds out human capital. This finding does not fit with the results from regression [2.3] in which the volatility in commodity prices did have a negative effect on human capital accumulation. Thus, the evidence surrounding the relationship between human capital investment and CTOT volatility seems 
to be inconclusive and so further research on the human capital accumulation channel is warranted. But as the coefficient of CTOT volatility (growth) is significantly negative (positive) in regression [4.2], it appears that volatility harms growth via a reduction in physical capital accumulation. ${ }^{14}$

Moreover, Table 5 shows that export diversification has a significant positive effect on output growth for the full sample as well as for the two subsamples. It is also the case that export sophistication enhances both TFP growth and physical capital accumulation in commodity exporting countries, see Table 6 . These results are consistent with those obtained in Tables 3 and 4, implying that there is strong evidence that diversification of the economy, away from primary commodity exports towards more productive goods, should be high on the policy agenda of primary commodity dependant countries.

In all six regressions, the Hansen test statistic is well above the conventional significance level, meaning that the internal instruments used are valid and at the same that time there is no evidence of second-order serial correlation in the error terms. Moreover, the coefficients of the control variables that are significant all have the expected signs. Thus overall the results obtained using the alternative measure of volatility confirm the robustness of our findings in Sections 4.2.1 and 4.2.2 and provide evidence for the negative effects of CTOT volatility on physical capital accumulation and through that on the growth rate of real GDP per capita.

Finally, in line with the literature, we have defined primary commodity exporters as those countries for which the ratio of primary commodities to total exports exceed 50 percent, but to make sure that this particular cut-off point is not driving our results we also estimated all the regressions using 40 and 60 percent cut-off points and found the results to be robust to these changes. This is not surprising as increasing the cut-off point to 60 percent only reduces the sample by three countries while reducing it to 40 percent increases the number of countries by six. These estimations are not reported but are available upon request.

\section{Analysis Using Annual Data}

There are a number of advantages to using non-overlapping five-year averages, including the potential for removing business cycle fluctuations. However, the averaging itself induces a loss of information with no guarantee that the business cycle fluctuations are removed entirely. Moreover, the traditional GMM methodology employed in Section 4 does not take into account cross sectional heterogeneity or cross country dependencies that might be present in our sample. To overcome some of these issues and also to provide robustness checks for our five-year average results, we employ the Pooled Mean Group methodology, described in Section 5.1, using annual observations from 1970 to 2007. This method allows for heterogenous error variances, short-run coefficients and intercepts while it restricts the long-run coefficients to be the same across countries. We present the estimation results of the effects of (i) commodity terms of trade growth, (ii) its volatility, and (iii) a conditioning information set on growth and its sources, and contrast these results with those obtained in Section 4.

\footnotetext{
${ }^{14}$ To confirm the results in Section 4.2.2, we also estimated regressions [4.1] to [4.3] for the 56 net commodity importing countries in our sample. As expected we found no significant effect of $g_{C T O T}$ and $\sigma_{C T O T}$ on the three channels for these countries.
} 


\subsection{Pooled Mean Group (PMG) Methodology}

When panels of data are available, there are a number of alternative estimation methods that vary on the extent to which they account for parameter heterogeneity. At one extreme is the Mean Group (MG) approach in which separate equations are estimated for each country and the average of estimated coefficients across countries is examined. Pesaran and Smith (1995) show that the MG method produces consistent estimates of the average of the parameters when the time-series dimension of the data is sufficiently large. At the other extreme are the traditional estimators in which dynamics are simply pooled and treated as homogeneous. Early and prominent examples include fixed effects (FE), random effects (RE), and generalized methods of moments (GMM), described in Section 4.1. These methods are typically focused on solving the problem of fixed effect heterogeneity in the case of large $\mathrm{N}$ and small T panels; whereas they are not designed to correct for the endogeneity induced by the latent heterogeneity. Pesaran and Smith (1995) show that the traditional procedures for estimation of pooled models can produce inconsistent and potentially misleading estimates of the lagged dependent variable's parameter in dynamic panel data models if latent heterogeneity is present.

In between the two extremes is the pooled mean group (PMG) estimator of Pesaran et al. (1999) which is an intermediate case between the averaging and pooling methods of estimation, and involves aspects of both. It restricts the long-run coefficients to be homogenous over the cross-sections, but allows for heterogeneity in intercepts, short-run coefficients (including the speed of adjustment) and error variances. The PMG estimator also generates consistent estimates of the mean of short-run coefficients across countries by taking the simple average of individual country coefficients. It can be argued that country heterogeneity is particularly relevant in short-run relationships, given that countries are affected by over lending, borrowing constraints, and financial crises in short-time horizons, albeit to different degrees. On the other hand there are often good reasons to expect that long-run relationships between variables are homogeneous across countries. Estimators that impose cross-sectional restrictions (PMG) dominate the fully heterogeneous ones (MG) in terms of efficiency if the long-run restrictions are indeed valid. If the constraints are not valid, however, the restricted estimators are inconsistent. ${ }^{15}$ To re-examine the long run relationship between CTOT volatility and growth, we make use of the PMG estimator (that is augmented to correct for cross-sectional dependencies that arise from common shocks) because it offers the best available choice in terms of consistency and efficiency in our sample of countries while it corrects at the same time for the shortcomings of homogeneous panel methods mentioned above.

The PMG estimator is based on an autoregressive distributive lag (ARDL) model and thus can be used for long-run analysis. In a series of papers, Pesaran and Smith (1995), Pesaran (1997), and Pesaran and Shin (1999) show that one can use the ARDL approach to produce consistent and efficient estimates of the parameters in a long-run relationship between both integrated and stationary variables, and to conduct inference on these parameters using standard tests. This method avoids the need for pre-testing the order of integration given that they are valid whether the variables of interest are $I(0)$ or $I(1)$. The main requirements for the validity of this methodology are that, first, there exists a long-run

\footnotetext{
${ }^{15}$ Robertson and Symons (1992) and Pesaran and Smith (1995) show that imposing invalid parameter homogeneity in dynamic models typically leads to downward biased estimates of the speed of adjustment.
} 
relationship among the variables of interest and, second, the dynamic specification of the model is sufficiently augmented so that the regressors are strictly exogenous and the resulting residual is serially uncorrelated. To explain the the PMG estimator in more detail, consider the following $A R D L(p, q, q, \ldots, q)$ model:

$$
y_{i t}=\sum_{j=1}^{p} \lambda_{i j} y_{i t-j}+\sum_{j=0}^{q} \delta_{i j}^{\prime} \mathbf{x}_{i t-j}+\mu_{i}+u_{i t}
$$

where $\mathbf{x}_{i t}$ is the $k \times 1$ vector of explanatory variables for group $i, \mu_{i}$ represents the fixed effects, the coefficients of the lagged dependent variables, $\lambda_{i j}$, are scalars and $\delta_{i j}$ are $k \times 1$ coefficient vectors. We assume that the error term, $u_{i t}$, has the following multi-factor error structure:

$$
u_{i t}=\boldsymbol{\tau}_{i}^{\prime} \mathbf{f}_{t}+\varepsilon_{i t}
$$

where $\mathbf{f}_{t}$ is a vector of unobserved common shocks, which can be stationary or nonstationary, see Kapetanios et al. (2010). The individual-specific errors, $\varepsilon_{i t}$, are distributed independently across $i$ and $t$; they are not correlated with the unobserved common factors or the regressors; and they have zero mean, variance greater than zero, and finite fourth moments. These common factor effects may be captured by adding cross sectional averages of the observables to our regressions, see Pesaran (2006) and Binder and Offermanns (2008). As always T must be large enough so that the model can be estimated for each cross-section. Equation (15) can be re-parameterized as:

$$
\Delta y_{i t}=\phi_{i} y_{i t-1}+\beta_{i}^{\prime} \mathbf{x}_{i t}+\sum_{j=1}^{p-1} \lambda_{i j}^{*} \Delta y_{i t-j}+\sum_{j=0}^{q-1} \delta_{i j}^{* \prime} \Delta \mathbf{x}_{i t-j}+\mu_{i}+u_{i t}
$$

where

$$
\phi_{i}=-\left(1-\sum_{j=1}^{p} \lambda_{i j}\right), \beta_{i}=\sum_{j=0}^{q} \delta_{i j}, \lambda_{i j}^{*}=-\sum_{m=j+1}^{p} \lambda_{i m}, \text { and } \delta_{i j}^{*}=-\sum_{m=j+1}^{q} \delta_{i m} .
$$

In addition, the roots of equation (17) must lie outside the unit circle to ensure that $\phi_{i}<0$, and hence that there exists a long-run relationship between $y_{i t}$ and $\mathbf{x}_{i t}$ defined by

$$
y_{i t}=\left(\frac{\beta_{i}^{\prime}}{\phi_{i}}\right) \mathbf{x}_{i t}+\eta_{i t}
$$

The long-run homogeneous coefficient is equal to $\theta=\theta_{i}=\left(\frac{\beta_{i}^{\prime}}{\phi_{i}}\right)$, which is the same across countries. The PMG estimator uses a maximum likelihood approach to estimate the model based on the Newton-Raphson algorithm. The lag length for the model can be determined using, for instance, the Schwarz Criterion (SBC).

\subsection{Empirical Results}

We use annual data on CTOT growth and volatility (obtained from GARCH(1,1) estimations) as well as GDP per capita growth and a set of control variables from 1970 to 2007 to 
investigate the hypothesized association between $g_{C T O T}, \sigma_{C T O T}$ and economic growth as well as its sources. Given the requirements on the time-series dimension of the panel, we include only countries for which we have at least 25 consecutive observations. In addition, in light of the results obtained in Section 4, we only focus on the sample of commodity exporters. This implies that our analysis will include 52 countries out of the 62 primary commodity exporters in our dataset, see Table 1.

As data on secondary enrollment used in the GMM regressions is only available in five year intervals, we cannot use the education variable in the PMG estimations. This also implies that we are unable to look at the human capital accumulation channel in Section 5.2.2 and therefore we will focus on the remaining two channels of impact on growth: TFP and physical capital investment equations.

\subsubsection{Volatility and Growth}

We use the PMG method described above to estimate the following equation:

$$
\begin{aligned}
\Delta y_{i t}= & \phi_{i} y_{i t-1}+\beta_{i}^{\prime} \mathbf{x}_{i t}+\sum_{j=1}^{p-1} \lambda_{i j}^{*} \Delta y_{i t-j}+\sum_{j=0}^{q-1} \delta_{i j}^{* \prime} \Delta \mathbf{x}_{i t-j}+\mu_{i}+\varepsilon_{i t} \\
& +a_{i} \bar{y}_{t}+b_{i} \bar{g}_{C T O T, t}+\sum_{j=0}^{p-1} c_{i j}^{*} \Delta \bar{y}_{t-j}+\sum_{j=0}^{q-1} d_{i j}^{*} \Delta \bar{g}_{C T O T, t-j},
\end{aligned}
$$

where $\Delta y_{i t}$ is the growth rate of real GDP per capita for country $i$ and year $t, \mathbf{x}_{i t}$ is a $5 \times 1$ vector of explanatory variables including the growth rate of the CTOT index, $g_{C T O T, i t}$, and its volatility, $\sigma_{C T O T, i t}$, as well as the conventional control variables: openness, government burden, and lack of price stability. $\mu_{i}$ is the country-specific effect and $\varepsilon_{i t}$ is the error term with a zero mean and constant variance. $\bar{y}_{t}, \Delta \bar{y}_{t}$ and $\bar{g}_{C T O T, t}$ denote the simple cross section averages of $y_{i t}, \Delta y_{i t}$ and $g_{C T O T, i t}$ in year $t$.

The consistency and efficiency of the PMG estimates rely on several specification conditions. ${ }^{16}$ Firstly, the order of the ARDL process must be chosen to be long enough to ensure that residuals of the error-correction model are exogenous and serially uncorrelated. At the same time, with a limited number of time-series observations, the ARDL order should not be overextended as this imposes excessive parameter requirements on the data. Note that the lag order is chosen on the unrestricted model, and then the homogeneity (long run) restrictions are imposed. We try to fulfill these conditions by allowing the lag order to be chosen by the Schwarz Criterion (SBC) subject to a maximum lag of two on each of the variables, in other words $p=q \leq 2$.

The second condition is cross sectional independence of the residuals $\varepsilon_{i t}$. Cross country dependencies arise from omitted common factors (e.g. time-specific effects or common shocks) that might influence the countries differently. We try to eliminate these common factors and to some extent satisfy the independence condition by augmenting our regressions with cross sectional averages of the growth rate of real GDP and the CTOT index. Ideally

\footnotetext{
${ }^{16}$ There is no evidence of serial correlation, non-normality, functional form misspecification, or heteroskedasticity in most of the 52 countries in the sample. The results of the diagnostic tests are not reported in the paper but are available upon request.
} 
we would also like to include the cross sectional averages of all the variables in $\mathbf{x}_{i t}$ but given that this is not possible, as we would run into lack of degrees of freedom, we choose the two variables that we believe are highly dependent across countries in our sample.

The third condition refers to the existence of a long-run relationship (dynamic stability) between our variables and requires that the coefficient on the error-correction term $\left(\phi_{i}\right)$ be negative. Finally, the fourth condition for the efficiency of PMG estimator is the commonality of the long-run parameters across countries. In addition to the PMG results we also report the mean group estimates in all of our tables, which are averages of the individual country coefficients. The MG approach provides consistent estimates of the averages of long-run coefficients, although they are inefficient if homogeneity is present. Under long-run slope homogeneity, PMG estimates are consistent and efficient. We test for long-run homogeneity using the Hausman statistic for the coefficients on each of the explanatory variables and for all of them jointly based on the null of equivalence between the PMG and MG estimations, see Pesaran et al. (1996) for details. If we reject the null hypothesis (i.e. we obtain a probability value of $<0.05$ ), the homogeneity assumption on long run coefficients across countries is invalid. Note that there is no guarantee that the variance-covariance matrix of the Hausman statistic will be positive definite, and in some cases the test may not be applicable.

Table (7) presents the Mean Group and Pooled Mean Group estimates as well as the Hausman test statistics, distributed as chi-squared examining panel heterogeneity. ${ }^{17}$ According to the Hausman statistics, the homogeneity restriction is not rejected for individual parameters as well as jointly in all our regressions. ${ }^{18}$ Thus, we focus on the results obtained using the PMG estimator, which, given its gains in consistency and efficiency over the alternative MG estimator, is more appropriate.

The results in Table 7 indicate that the error correction coefficients, $\phi_{i}$, fall within the dynamically stable range (being statistically significant and negative), and therefore the null hypothesis of no long run relation is rejected. This finding indicates that there is strong evidence for conditional convergence to country specific steady states in our sample of 52 commodity exporting countries. This is in contrast to the results from the regressions in [1.2] and [3.2] and highlights that the strict homogeneity constraints imposed in the GMM estimations are too rigid to suggest convergence to a common steady state among all commodity exporters.

In the long run, the growth rate of GDP per capita is, as expected, significantly negatively related to the size of government as well as the lack of price stability, and significantly positively related to trade openness. Most importantly for our purposes, the PMG estimate of the commodity terms of trade volatility is negative and statistically significant which means that growth is adversely linked to commodity price volatility in the long run. Moreover, it is still the case that our measure of resource abundance, $g_{C T O T}$, is significantly positively

\footnotetext{
${ }^{17}$ The individual country results are not reported here but are available upon request.

${ }^{18}$ The likelihood ratio (LR) test always suggests that homogeneity is not a reasonable assumption in our regressions, as it does in the Pesaran et al. (1999) study of aggregate consumption. On the other hand, the Hausman test typically accepts poolability in the Pesaran et al. (1999) study as it does in our regressions. We focus largely on the Hausman test statistic based on the evidence provided by Pesaran et al. (1996). They examine the properties of the Hausman test by conducting a Monte Carlo study and show that when $\mathrm{T}$ is small relative to $\mathrm{N}$, as it is in our study, the Hausman test has reasonable size and power.
} 
related to economic growth, but its impact on real GDP per capita is smaller than that of CTOT volatility. This finding supports our previous results in Tables 3 and 5, suggesting that the source of the resource curse is the volatility of commodity prices as opposed to abundance per se. Overall, comparing the MG and PMG estimates, imposing long run homogeneity reduces the standard errors, increases the measured speed of adjustment and (slightly) changes the long run estimates.

\subsubsection{Volatility and the Channels to Economic Growth}

To investigate the channels through which commodity terms of trade volatility harms output growth, we estimate the following regression for each of the 52 countries before imposing the long-run homogeneity restrictions:

$$
\begin{aligned}
\Delta w_{i t}= & \phi_{i} w_{i t-1}+\beta_{i}^{\prime} \mathbf{x}_{i t}+\sum_{j=1}^{p-1} \lambda_{i j}^{*} \Delta w_{i t-j}+\sum_{j=0}^{q-1} \delta_{i j}^{* !} \Delta \mathbf{x}_{i t-j}+\mu_{i}+\varepsilon_{i t} \\
& +a_{i} \bar{w}_{t}+b_{i} \bar{g}_{C T O T, t}+\sum_{j=0}^{p-1} c_{i j}^{*} \Delta \bar{w}_{t-j}+\sum_{j=0}^{q-1} d_{i j}^{*} \Delta \bar{g}_{C T O T, t-j}
\end{aligned}
$$

where $w_{i t}=\{$ TFP or physical capital per capita for country $i$ and time $t\}$; and $\Delta w_{i t}$ is the growth rate of $w_{i t}$ while $\bar{w}_{t}$ and $\Delta \bar{w}_{t}$ are the simple cross sectional averages of $w_{i t}$ and $\Delta w_{i t}$, with all other variables as defined in equation (18). As the $p$-values of the Hausman tests in regressions [5.1] and [5.2] are well above the usual significance levels, we cannot reject the null hypothesis of long-run homogeneity and as such we concentrate on the PMG estimates for both the TFP and the physical capital investment equations.

Regression [5.1] confirms that TFP is not the channel through which uncertainty in commodity prices dampens growth, as the coefficient of CTOT volatility is insignificant, supporting the results in Sections 4.2.2 and 4.2.3. However, in contrast to our earlier findings using five-year averages, resource abundance measured by $g_{C T O T}$ negatively affects TFP growth. But as the overall effect of this variable on real GDP per capita growth in the long run is significantly positive, see Table 7 , it must be the case that the negative impact of $g_{C T O T}$ on TFP growth is offset through other channels. Overall, there seems to be no statistical evidence that commodity booms eventually lead to lower output growth, consequently ruling out the possibility that the Dutch disease effect is operating in the countries in our sample.

Turning to the physical capital accumulation channel, regression [5.2], we observe that the results presented in Table 8 are consistent with those obtained in Tables 4 and 6, as CTOT growth increases the capital stock and through that enhances the growth rate of real GDP per capita. More importantly, volatility reduces physical capital accumulation; indicating that this channel is one of the most important sources through which uncertainty in commodity prices dampens output growth.

The error correction term in regression [5.1] is in line with expectations, $\phi_{i}<0$, suggesting that there is some convergence towards the technological frontier across countries and thus positive knowledge spillovers. This is also true for the physical capital investment equation in [5.2]. Finally, while both government burden and lack of price stability have significantly negative effects on TFP growth, trade openness has a significant positive effect. The lack of 
price stability (openness) also significantly negatively (positively) affects the growth rate of physical capital stock, while government consumption boosts investment.

Thus, overall, the results of the PMG estimations are in line with those obtained in Section 4, suggesting that commodity price volatility has a negative impact on economic growth operating through lower capital investment. This result is also supported by a number of contributions in the literature, see Section 4.2.2, with emphasis on physical capital investment being the channel through which the resource curse operates. However, the focus of those papers, as elsewhere in the resource curse literature, is on the level of the resource income and not its volatility.

\section{Policy Implications}

This section studies the implications of our findings to countries that are members of the OPEC and the OECD as well as for countries in the MENA region. Table 9 contains the average value from 1970 to 2007 of the following variables: GDP per capita growth, CTOT growth, CTOT volatility, and a measure of export sophistication. Although we observe that GDP per capita growth in all of our four commodity exporting subsamples is lower than the average for the commodity importers this is not, as commonly believed, due to the abundance of natural resources. Given that our empirical results suggest that higher CTOT growth contributes positively to per capita GDP, we argue that the low growth rates can be attributed to the high CTOT volatility which these countries have experienced over time, see Table 9. Indeed average CTOT volatility is more than 3.5 times larger in commodity exporting countries.

Therefore, the question should not be whether having a large endowment of natural resources is bad or good for an economy, instead focus should be placed on how primary commodity exporting countries could be made better off by adopting growth and welfare enhancing policies and institutions to reduce the negative effects of CTOT volatility on capital accumulation and thus on economic growth. Some of these growth enhancing policies are:

i. Improving the functioning of financial markets. Well-developed financial market allows firms and households to insure against shocks, decreasing uncertainty and therefore the negative effects of volatility on investment and economic growth. Related to this, Aghion et al. (2009), for instance, show that higher levels of exchange rate volatility can hamper growth, especially in countries with less developed financial markets. Policies that might improve the functioning of financial markets are: (i) decreasing explicit and implicit taxes (e.g., non-interest reserve requirements) on banks and financial intermediaries; (ii) reforming or creating a bankruptcy law giving protection to creditors; and (iii) integrating the capital market to international markets.

ii. Another important policy for these countries is to diversify the production structure away from a small set of commodities. Our results show that export diversification can have a significant positive effect on economic growth, see Tables 3 and 5 . From Table 9 it is clear that in each subsample commodity exporters have an export diversification index lower than the mean of the commodity importers. Thus there are significant 
gains to be made from export diversification by for instance using resource rents to invest in technology to diversify the production structure.

iii. The exchange rate policies of resource abundant countries are shaped by the uncertainty about future price dynamics, exhaustible nature of oil, and adjustment costs in increasing investment; factors which are different from countries that are not dependent on a handful of primary products. The propensity to peg to the US dollar, or a basket of currencies, is a common feature of commodity-exporting countries. However, while most of these countries see the currency to which they are linked to moving in one direction, their principal export commodities prices move in the opposite direction. Furthermore, owing to volatile commodity prices (especially oil) and a weak US dollar, the choice of a nominal anchor for commodity-exporting countries has more recently taken centre stage in policy debates again.

The results of our paper have indirect policy implications for the choice of an exchangerate regime for commodity-exporting economies. We argue, in line with what is being suggested by Frankel (2003), the case for including commodity prices as a component of the monetary policy anchor, given the significant correlation of business cycles in the natural resource-dependent countries with commodity prices.

Different monetary regimes have indeed been suggested in the literature including a dollar or euro peg, a peg to a basket of currencies such as the special drawing rights (SDR), a managed floating exchange rate, or simply a peg to the export price of oil. Supporters of hard pegs have argued that this type of regime provides credibility and results in lower inflation, a more stable economic environment and faster economic growth. Supporters of flexibility, on the other hand, have argued that under floating exchange rates the economy has a greater ability to adjust to external shocks. We argue that pegging the exchange rate to the price of a main export commodity (or at least including commodity prices in the pegging basket) may be useful as an automatic adjustment mechanism in response to commodity terms of trade shocks. Motivated by the proposition above, we intend to explore this idea and the consequences of using commodity prices as a nominal anchor for monetary policy in a companion paper.

iv. Finally, resource-rich countries can address the volatility problem by establishing Sovereign Wealth Funds (if they have substantial revenues from their exports) or adopt a short-term mechanism such as stabilization funds with the aim to save when commodity prices are high in order to use these revenues in times when prices are low. The government can also intervene in the economy by increasing public investment when private investment is low using the proceeds from the stabilization fund. Alternatively the government can use these funds to increase the complementarities of physical and human capital, such as improving the judicial system, property rights, and human capital level. This would increase the returns on investment with positive effects on capital accumulation and growth. 


\section{Concluding Remarks}

This paper examined empirically the effects of commodity price booms and terms of trade volatility on GDP per capita growth as well as its sources using two econometric techniques. First, we employed a system GMM dynamic panel estimator to deal with the problems of simultaneity and omitted variables bias, derived from unobserved country-specific effects. Second, we created an annual panel dataset to exploit the time-series nature of the data and used an augmented Pooled Mean Group (PMG) estimator to account for both cross-country heterogeneity and cross-sectional dependence which arise from unobserved common factors. The hypothesis was that commodity terms of trade volatility affects output growth negatively, operating mainly through the capital accumulation channel. This hypothesis is shown to be largely validated by our time series panel data method as well as the system GMM technique used, suggesting the importance of volatility for explaining the under-performance of primary commodity dependent countries.

While the resource curse hypothesis predicts a negative effect of resource abundance (proxied by commodity booms) on output growth, the empirical results presented in this paper show the contrary: commodity terms of trade growth seems to have impacted the primary-product exporters positively. Since the negative impact of CTOT volatility on GDP per capita is larger than the growth enhancing effects of commodity booms, we argued that volatility rather than abundance per se drives the resource curse paradox. We also showed that the channel through which volatility affects growth adversely is the physical capital accumulation. Furthermore, in the GMM regressions, we found that uncertainty in commodity prices could also crowd out investment in human capital and consequently stunt output growth, but this is not a robust result when we use the GARCH approach to calculate CTOT volatility. Further research is needed to determine how countries can offset the negative effects of commodity price uncertainty on physical and human capital investment.

Another notable aspect of our results is the asymmetric effects of commodity terms of trade volatility on GDP per capita growth in the two subsamples considered. While CTOT instability created a significant negative effect on output growth in the sample of 62 primary product exporters, elsewhere in the remaining 56 countries or even in the full sample of 118 countries the same pattern was not observed. One explanation for this observation is that the latter group of countries, with more diversified export structure, were better able to insure against price volatility than the sample of primary product exporters. Finally, we offered some empirical evidence on growth enhancing effects of export diversification, especially for countries whose GDP is highly dependant on revenues from just a handful of primary products.

The empirical results presented here have strong policy implications. Improvements in the conduct of macroeconomic policy, better management of resource income volatility through Sovereign Wealth Funds (SWF) as well as stabilization funds, a suitable exchange rate regime, and export diversification can all have beneficial growth effects. Moreover, recent academic research has put emphasis on institutional reform. By setting up the right institutions one can ensure the proper conduct of macroeconomic policy and better use of resource income revenues, thereby increasing the potential for growth. We await better data on institutional quality with higher frequencies to test this hypothesis. Clearly, fully 
articulated structural models are needed to properly investigate the channels through which the negative growth effects of volatility could be attenuated. This remains an important challenge for future research. 


\section{References}

Aghion, P., P. Bacchetta, R. Rancière, and K. Rogoff (2009). Exchange Rate Volatility and Productivity Growth: The role of Financial Development. Journal of Monetary Economics $56(4), 494-513$.

Aizenman, J. and B. Pinto (2005). Managing Volatility and Crises: A Practitioner's Guide Overview. In J. Aizenman and B. Pinto (Eds.), Managing Economic Volatility and Crises: A Practitioner's Guide. Cambridge University Press, Cambridge.

Alexeev, M. and R. Conrad (2009). The Elusive Curse of Oil. The Review of Economics and Statistics $91(3)$, 586-598.

Alonso-Borrego, C. and M. Arellano (1999). Symmetrically Normalized InstrumentalVariable Estimation Using Panel Data. Journal of Business 8 Economic Statistics 17(1), $36-49$.

Anderson, T. W. and C. Hsiao (1982). Formulation and Estimation of Dynamic Models Using Panel Data. Journal of Econometrics 18(1), 47-82.

Arellano, M. and S. Bond (1991). Some Tests of Specification for Panel Data: Monte Carlo Evidence and an Application to Employment Equations. The Review of Economic Studies 58(2), 277-297.

Arellano, M. and O. Bover (1995). Another Look at the Instrumental Variable Estimation of Error-components Models. Journal of Econometrics 68(1), 29-51.

Barro, R. J. and J.-W. Lee (2010). A New Data Set of Educational Attainment in the World, 1950Ü2010. NBER Working Paper Series 15902.

Beck, T., R. Levine, and N. Loayza (2000). Finance and the Sources of Growth. Journal of Financial Economics 58(1-2), 261 - 300.

Binder, M. and C. J. Offermanns (2008). International Investment Positions and Exchange Rate Dynamics: A Dynamic Panel Analysis. Working Paper.

Birdsall, N., T. Pinckney, and R. Sabot (2001). Natural Resources, Human Capital, and Growth. In R. Auty (Ed.), Resource Abundance and Economic Growth. Oxford University Press, Oxford.

Blattman, C., J. Hwang, and J. G. Williamson (2007). Winners and Losers in the Commodity Lottery: The Impact of Terms of Trade Growth and Volatility in the Periphery 1870-1939. Journal of Development Economics 82(1), 156 - 179.

Bleaney, M. and D. Greenaway (2001). The Impact of Terms of Trade and Real Exchange Rate Volatility on Investment and Growth in Sub-Saharan Africa. Journal of Development Economics 65(2), 491 - 500.

Blundell, R. and S. Bond (1998). Initial Conditions and Moment Restrictions in Dynamic Panel Data Models. Journal of Econometrics 87(1), 115 - 143. 
Bravo-Ortega, C., J. De Gregorio, and D. Paraguay (2005). The Relative Richness of the Poor? Natural Resources, Human Capital, and Economic Growth. The World Bank: Policy Research Working Paper Series 3484.

Brunnschweiler, C. N. and E. H. Bulte (2008). The Resource Curse Revisited and Revised: A Tale of Paradoxes and Red Herrings. Journal of Environmental Economics and Management 55(3), 248-264.

Bulte, E. H., R. Damania, and R. T. Deacon (2005). Resource Intensity, Institutions, and Development. World Development 33(7), 1029-1044.

Cavalcanti, T., K. Mohaddes, and M. Raissi (2009). Growth, Development and Natural Resources: New Evidence Using a Heterogeneous Panel Analysis. Cambridge Working Papers in Economics 0946 .

Cavalcanti, T., K. Mohaddes, and M. Raissi (2010). Does Oil Abundance Harm Growth? Applied Economics Letters Forthcoming.

Corden, W. M. and J. P. Neary (1982). Booming Sector and De-Industrialisation in a Small Open Economy. The Economic Journal 92(368), 825-848.

Esfahani, H. S., K. Mohaddes, and M. H. Pesaran (2009). Oil Exports and the Iranian Economy. Cambridge Working Papers in Economics 0944.

Frankel, J. (2003). A Proposed Monetary Regime for Small Commodity Exporters: Peg the Export Price ('PEP'). International Finance 6, 61-88.

Gylfason, T. (2001). Natural Resources, Education, and Economic Development. European Economic Review 45(4-6), 847-859.

Gylfason, T. (2006). Natural Resources and Economic Growth: From Dependence to Diversification. In H. G. Broadman, T. Paas, and P. J. Welfens (Eds.), Economic Liberalization and Integration Policy. Springer.

Gylfason, T., T. T. Herbertsson, and G. Zoega (1999). A Mixed Blessing. Macroeconomic Dynamics 3(02), 204-225.

Gylfason, T. and G. Zoega (2006). Natural Resources and Economic Growth: The Role of Investment. World Economy 29(8), 1091-1115.

Hall, R. and C. Jones (1999). Why Do Some Countries Produce So Much More Output Per Worker Than Others? Quarterly Journal of Economics 114(1), 83-116.

Hausmann, R., J. Hwang, and D. Rodrik (2007). What You Export Matters. Journal of Economic Growth Volume 12, Number 1, 1-25.

Heston, A., R. Summers, and B. Aten (2009). Penn World Table Version 6.3. Center for International Comparisons of Production, Income and Prices at the University of Pennsylvania. 
International Monetary Fund, . (2010). World Economic Outlook.

Kapetanios, G., M. H. Pesaran, and T. Yamagata (2006 (Revised April 14, 2010)). Panels with Nonstationary Multifactor Error Structures. Cambridge Working Papers in Economics 0651.

Krugman, P. (1987). The Narrow Moving Band, the Dutch Disease, and the Competitive Consequences of Mrs. Thatcher: Notes on Trade in the Presence of Dynamic Scale Economies. Journal of Development Economics 27(1-2), 41-55.

Lee, J., G. M. Milesi-Ferretti, J. Ostry, A. Prati, and L. A. Ricci (2008). Exchange Rate Assessments: CGER Methodologies. IMF Occasional Paper No. 261.

Levine, R., N. Loayza, and T. Beck (2000). Financial Intermediation and Growth: Causality and Causes. Journal of Monetary Economics 46(1), $31-77$.

Neary, J. P. and S. J. G. van Wijnbergen (1986). Natural Resources and the Macroeconomy. MIT Press, Cambridge, MA.

Papyrakis, E. and R. Gerlagh (2004). The Resource Curse Hypothesis and its Transmission Channels. Journal of Comparative Economics 32(1), 181 - 193.

Pesaran, M. H. (1997). The Role of Economic Theory in Modelling the Long Run. The Economic Journal 107(440), 178-191.

Pesaran, M. H. (2006). Estimation and Inference in Large Heterogeneous Panels with a Multifactor Error Structure. Econometrica 74(4), 967-1012.

Pesaran, M. H. and Y. Shin (1999). An Autoregressive Distributed Lag Modeling Approach to Cointegration Analysis, in Storm, S., ed, Econometrics and Economic Theory in the 20th Century: the Ragnar Frish Centennial Symposium.

Pesaran, M. H., Y. Shin, and R. P. Smith (1999). Pooled Mean Group Estimation of Dynamic Heterogeneous Panels. Journal of the American Statistical Association 94(446), 621-634.

Pesaran, M. H. and R. Smith (1995). Estimating Long-run Relationships from Dynamic Heterogeneous Panels. Journal of Econometrics 68(1), 79-113.

Pesaran, M. H., R. P. Smith, and K. S. Im (1996). Dynamic Linear Models for Heterogeneous Panels. In L. Matyas and P. Sevestre (Eds.), The Economics of Panel Data: A Handbook of Theory With Applications, Chapter 8. Kluwer Academic Publishers.

Psacharopoulos, G. (1999). Returns to Investment in Education: A Global Update. World Development 22(9), 1325-1343,.

Psacharopoulos, G. and H. A. Patrinos (2004). Returns to Investment in Education: A Further Update. Education Economics 12(2), 111-134. 
Ramey, G. and V. A. Ramey (1995). Cross-Country Evidence on the Link Between Volatility and Growth. The American Economic Review 85(5), 1138-1151.

Robertson, D. and J. Symons (1992). Some Strange Properties of Panel Data Estimators. Journal of Applied Econometrics 7(2), 175-189.

Rodriguez, F. and J. D. Sachs (1999). Why Do Resource-Abundant Economies Grow More Slowly? Journal of Economic Growth 4, 277-303.

Rosser, A. (2006). The Political Economy of the Resource Curse: A Literature Survey. Institute of Development Studies Working Paper 268.

Sachs, J. D. and A. M. Warner (1995). Natural Resource Abundance and Economic Growth. National Bureau of Economic Research Working Paper 5398.

Serven, L. (2003). Real-Exchange-Rate Uncertainty and Private Investment in LDCs. Review of Economics and Statistics 85(2), 492-492.

Spatafora, N. and I. Tytell (2009). Commodity Terms of Trade: The History of Booms and Busts. IMF Working Paper No. 09/205.

Stijns, J.-P. C. (2005). Natural Resource Abundance and Economic Growth Revisited. Resources Policy 30(2), 107-130.

UNESCO, . (2010). UIS Education Statistics.

van der Ploeg, F. and S. Poelhekke (2009). Volatility And The Natural Resource Curse. Open Access publications from University of Oxford.

van der Ploeg, F. and S. Poelhekke (2010). The Pungent Smell of "Red Herrings": Subsoil Assets, Rents, Volatility and the Resource Curse. Journal of Environmental Economics and Management 60(1), 44-55.

van der Ploeg, F. and T. Venables (2009). Symposium on Resource Rich Economies Introduction. Oxford Economic Papers 61(4), 625-627.

Windmeijer, F. (2005). A Finite Sample Correction for the Variance of Linear Efficient Two-step GMM Estimators. Journal of Econometrics 126(1), 25 - 51.

World Bank, . (2010). World Development Indicators. 


\section{Tables and Figures}

\section{Table 1: List of the 118 Countries in the Sample}

\begin{tabular}{|c|c|c|c|}
\hline Albania & Ecuador $^{1,2,4}$ & Lithuania & Sierra Leone $e^{1,2}$ \\
\hline Algeria $^{1,2,3,4}$ & Egypt $^{1,2,3}$ & Malawi $^{1,2}$ & Slovak Republic ${ }^{5}$ \\
\hline Argentina $^{1,2}$ & El Salvador & Malaysia & Slovenia $^{5}$ \\
\hline Armenia $^{1}$ & Fiji ${ }^{1,2}$ & Mali $^{1,2}$ & South Africa \\
\hline Australia $^{1,2,5}$ & Finland $^{5}$ & Mauritania $^{1,2}$ & Spain $^{5}$ \\
\hline Austria $^{5}$ & France $^{5}$ & Mauritius & Sri Lanka \\
\hline Bahrain, Kingdom of ${ }^{1,3}$ & Gabon $^{1,2,4}$ & Mexico $^{5}$ & Sudan $^{1,2,3}$ \\
\hline Bangladesh & Gambia, The $\mathrm{e}^{1,2}$ & Moldova $^{1}$ & Swaziland \\
\hline Belgium $^{5}$ & Germany $^{5}$ & Morocco $^{3}$ & Sweden $^{5}$ \\
\hline Benin $^{1,2}$ & Ghana $^{1,2}$ & Mozambique $^{1,2}$ & Switzerland $^{5}$ \\
\hline Bolivia $^{1,2}$ & Greece $^{5}$ & Namibia $^{1,2}$ & Syrian Arab Republic ${ }^{1,2,3}$ \\
\hline Botswana $^{1,2}$ & Guatemala $^{1,2}$ & Nepal & Tajikistan $^{1}$ \\
\hline Brazil & Guyana $^{1,2}$ & Netherlands ${ }^{5}$ & Tanzania $^{1}$ \\
\hline Bulgaria & Honduras ${ }^{1,2}$ & New Zealand $d^{1,2,5}$ & Thailand \\
\hline Burundi ${ }^{1,2}$ & Hungary $^{5}$ & Nicaragua $^{1,2}$ & $\operatorname{Tog}_{0}^{1,2}$ \\
\hline Cambodia & India & Niger $^{1,2}$ & Trinidad and Tobago ${ }^{1,2}$ \\
\hline Cameroon $^{1,2}$ & Indonesia $^{1,2,4}$ & Norway $^{1,2,5}$ & Tunisia $^{3}$ \\
\hline Canada $^{5}$ & Iran, I.R. of ${ }^{1,2,3,4}$ & Pakistan & Turkey $^{5}$ \\
\hline Central African Rep. ${ }^{1,2}$ & Ireland $^{5}$ & Panama ${ }^{1,2}$ & Uganda $^{1}$ \\
\hline Chile $^{1,2,5}$ & Israel $^{3,5}$ & Papua New Guinea ${ }^{1,2}$ & Ukraine \\
\hline China, People's Rep. of & Italy $^{5}$ & Paraguay $^{1,2}$ & United Arab Emirates ${ }^{1,2,3,4}$ \\
\hline Colombia ${ }^{1,2}$ & Japan $^{5}$ & Peru ${ }^{1,2}$ & United Kingdom $^{5}$ \\
\hline Congo, Republic of ${ }^{1,2}$ & Jordan $^{3}$ & Philippines & United States $^{5}$ \\
\hline Costa Rica & Kazakhstan $^{1}$ & Poland ${ }^{5}$ & Uruguay $^{1,2}$ \\
\hline Côte d'Ivoire ${ }^{1,2}$ & Kenya $^{1,2}$ & Portugal $^{5}$ & Venezuela, Rep. Bol. ${ }^{1,2,4}$ \\
\hline Croatia & Korea $^{5}$ & Romania & Vietnam \\
\hline Cyprus $^{1}$ & Kuwait $^{1,2,3,4}$ & Russia $^{1}$ & Zambia $^{1,2}$ \\
\hline Czech Republic ${ }^{5}$ & Kyrgyz Republic ${ }^{1}$ & Rwanda $^{1,2}$ & Zimbabwe $^{1,2}$ \\
\hline Denmark $^{5}$ & Latvia & Saudi Arabia ${ }^{1,2,3,4}$ & \\
\hline Dominican Republic & Lesotho & Senegal $^{1,2}$ & \\
\hline
\end{tabular}

Notes: 1 indicates that the country is a commodity exporter. Countries are classified as commodity exporters if primary commodities constitute more than 50 percent of their exports. 62 countries in the sample are primary commodity exporters and 56 are not. The 52 countries that are included in the Pooled Mean Group analysis of Section 5 are denoted by ${ }^{2}$. The Middle East and North African (MENA) countries are denoted by ${ }^{3}$, whereas members of the Organization of the Petroleum Exporting Countries (OPEC) and of the Organisation for Economic Co-operation and Development (OECD) are denoted by ${ }^{4}$ and ${ }^{5}$ respectively. 


\section{Table 2: Definitions and Sources of Variables Used in Regression Analysis}

\begin{tabular}{|c|c|c|}
\hline Variable & Definition and Construction & Source \\
\hline Real GDP per Capita & Ratio of GDP (in 2000 US\$) to population. & \\
\hline GDP per Capita Growth & $\begin{array}{l}\text { Geometric average growth rate } \\
\text { of real GDP per capita. }\end{array}$ & $\begin{array}{l}\text { Authors' construction using data from } \\
\text { the World Bank (2010) World } \\
\text { Development Indicators (WDI). }\end{array}$ \\
\hline Initial GDP per Capita & $\begin{array}{l}\text { Initial value of GDP per capita in the } \\
\text { beginning of each five-year period. }\end{array}$ & \\
\hline TFP & Total factor productivity (TFP). & \\
\hline TFP Growth & Geometric average growth rate of TFP. & \\
\hline Initial TFP & $\begin{array}{l}\text { Initial value of TFP in the beginning of } \\
\text { each five-year period. }\end{array}$ & \\
\hline Physical Capital per Capita & Ratio of physical capital to population. & $\begin{array}{l}\text { Authors' construction using data from } \\
\text { Heston et al. ( } 2009) \text {. } \\
\text { See Section } 3 \text { for more details. }\end{array}$ \\
\hline Physical Capital per Capita Growth & $\begin{array}{l}\text { Geometric growth rate of physical } \\
\text { capital per capita. }\end{array}$ & \\
\hline Initial Physical Capital Per Capita & $\begin{array}{l}\text { Initial value of the ratio of total physical } \\
\text { capital to total population in the } \\
\text { beginning of each five-year period. }\end{array}$ & \\
\hline Human Capital per Capita & Ratio of human capital to population. & \\
\hline Human Capital per Capita Growth & $\begin{array}{l}\text { Geometric growth rate of human } \\
\text { capital per capita. }\end{array}$ & $\begin{array}{l}\text { Authors' construction using data from } \\
\text { Barro and Lee (2010). }\end{array}$ \\
\hline Initial Human Capital per Capita & $\begin{array}{l}\text { Initial value of the ratio of total human } \\
\text { capital to total population in the } \\
\text { beginning of each five-year period. }\end{array}$ & \\
\hline Commodity Terms of Trade Growth & $\begin{array}{l}\text { Growth rate of commodity } \\
\text { terms of trade index. }\end{array}$ & $\begin{array}{l}\text { Authors' construction based on } \\
\text { Spatafora and Tytell (2009). }\end{array}$ \\
\hline Commodity Terms of Trade Volatility & $\begin{array}{l}\text { Standard deviation of commodity terms } \\
\text { of trade growth in five-year interval. }\end{array}$ & \\
\hline Export Sophistication Measure & $\begin{array}{l}\text { A measure of the productivity level associated } \\
\text { with a country's specialization pattern. }\end{array}$ & $\begin{array}{l}\text { Authors' construction based on } \\
\text { Hausmann et al. (2007) and } \\
\text { the World Bank (2010) WDI. }\end{array}$ \\
\hline Education & $\begin{array}{l}\text { Ratio of total secondary enrollment to the } \\
\text { population of the age group that officially } \\
\text { corresponds to that level of education. }\end{array}$ & $\begin{array}{l}\text { Authors' construction using data from } \\
\text { UNESCO (2010) UIS. }\end{array}$ \\
\hline & Ratio of Exports and Imports to GDP. & $\begin{array}{l}\text { Authors' construction using data from } \\
\text { the World Bank (2010) WDI. }\end{array}$ \\
\hline Government Burden & Ratio of government consumption to GDP. & \\
\hline CPI & $\begin{array}{l}\text { Consumer price index }(2000=100) \text { at } \\
\text { the end of the year. }\end{array}$ & \\
\hline Inflation rate & Annual percentage change in CPI. & $\begin{array}{l}\text { Author's calculations using data from } \\
\text { the International Monetary Fund (2010) } \\
\text { World Economic Outlook. }\end{array}$ \\
\hline Lack of Price Stability & $\log (100+$ inflation rate $)$ & \\
\hline
\end{tabular}




\section{Figure 1: Commodity Terms of Trade Growth and Volatility}

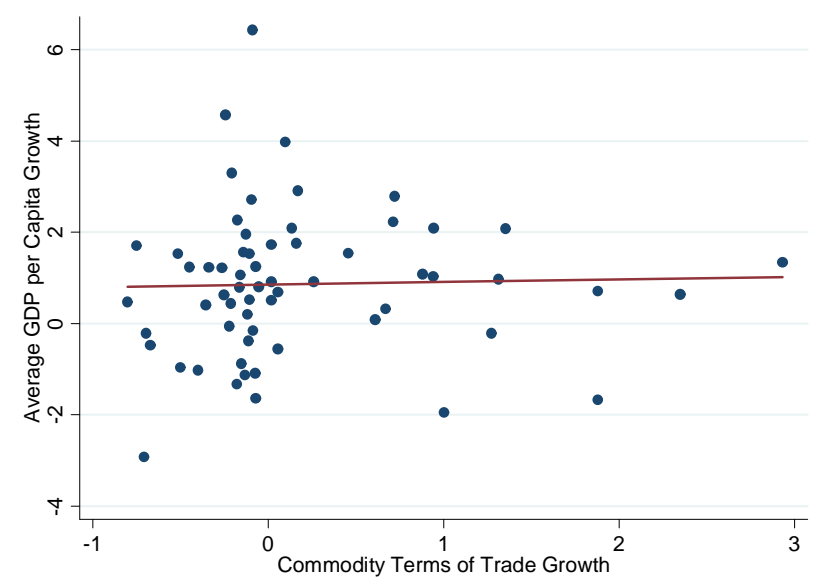

Primary Commodity Exporters (62)

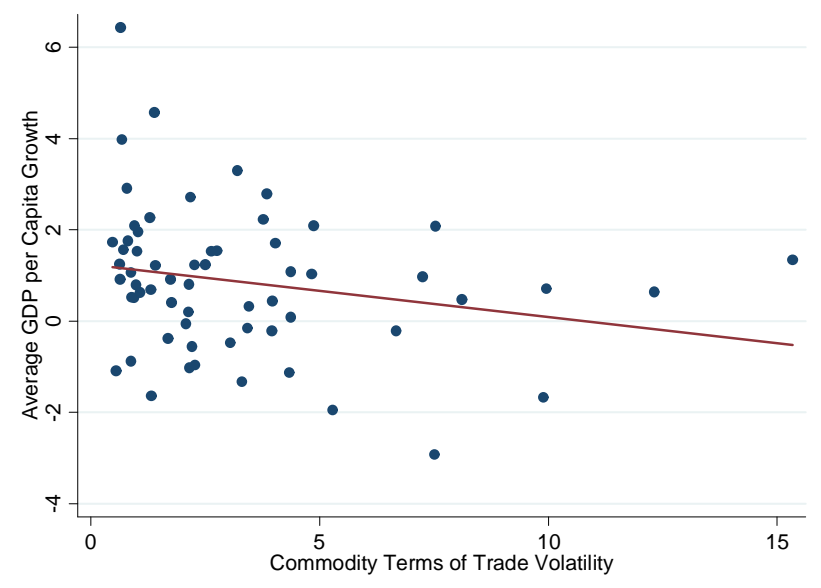

Primary Commodity Exporters (62)

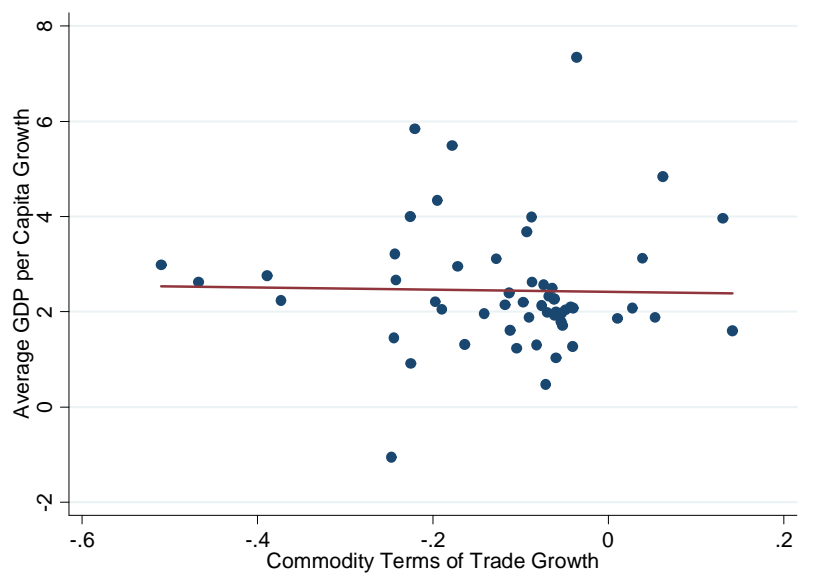

All Other Countries (56)

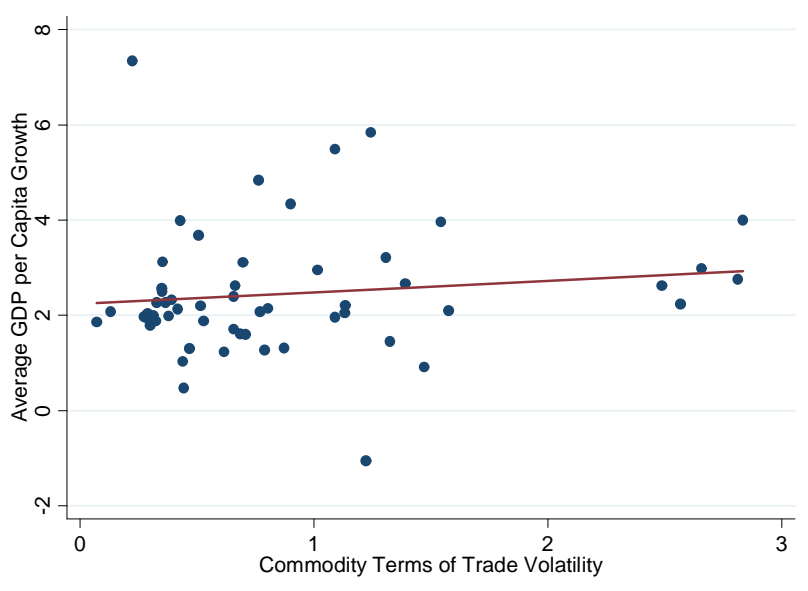

All Other Countries (56)

Notes: Average GDP per capita growth is the geometric growth rate of real per capita GDP between 1970 and 2007 and is in percent. Commodity terms of trade growth is the mean growth rate of the CTOT index, defined in (1), over 1970 to 2007. CTOT volatility is the standard deviation of the growth rate of the commodity terms of trade index and is calculated using data from 1970 to 2007. Primary commodity exporters are those countries for which the ratio of primary commodities to total exports exceed 50 percent. 
Table 3: Growth Effects of CTOT Volatility I

Unit of Observation, Period:

Volatility Measure:
Non-overlapping five-year averages, 1970 - 2005

Five year standard deviation of annual CTOT growth

\begin{tabular}{|c|c|c|c|}
\hline & \\
\hline & {$[1.1]$} & {$[1.2]$} & {$[1.3]$} \\
\hline Initial Output per Capita, in logs & $\begin{array}{c}-1.204^{* *} \\
(0.471)\end{array}$ & $\begin{array}{l}-0.872 \\
(0.688)\end{array}$ & $\begin{array}{c}-1.738^{* * *} \\
(0.546)\end{array}$ \\
\hline Commodity Terms of Trade Growth & $\begin{array}{c}0.240^{* * *} \\
(0.072)\end{array}$ & $\begin{array}{c}0.255^{* * *} \\
(0.078)\end{array}$ & $\begin{array}{l}-0.156 \\
(0.469)\end{array}$ \\
\hline Commodity Terms of Trade Volatility & $\begin{array}{l}-0.105 \\
(0.081)\end{array}$ & $\begin{array}{c}-0.119^{* *} \\
(0.058)\end{array}$ & $\begin{array}{l}-0.683 \\
(0.577)\end{array}$ \\
\hline Export Sophistication Measure, in logs & $\begin{array}{c}4.818^{* * *} \\
(1.830)\end{array}$ & $\begin{array}{l}2.787^{*} \\
(1.638)\end{array}$ & $\begin{array}{c}3.687^{* *} \\
(1.465)\end{array}$ \\
\hline $\begin{array}{l}\text { Control variables } \\
\text { Education } \\
\text { (secondary enrollment, in logs) }\end{array}$ & $\begin{array}{c}0.812 \\
(0.803)\end{array}$ & $\begin{array}{l}1.256 \\
(0.960)\end{array}$ & $\begin{array}{c}0.054 \\
(1.380)\end{array}$ \\
\hline $\begin{array}{l}\text { Trade Openness } \\
\text { (trade volume/GDP, in logs) }\end{array}$ & $\begin{array}{c}2.027^{* *} \\
(1.024)\end{array}$ & $\begin{array}{c}2.587^{* * *} \\
(0.860)\end{array}$ & $\begin{array}{c}2.142^{* *} \\
(0.929)\end{array}$ \\
\hline $\begin{array}{l}\text { Government Burden } \\
\text { (government consumption/GDP, in logs) }\end{array}$ & $\begin{array}{c}-2.656^{* *} \\
(1.163)\end{array}$ & $\begin{array}{c}-4.007^{* * *} \\
(1.064)\end{array}$ & $\begin{array}{c}-0.109 \\
(1.536)\end{array}$ \\
\hline $\begin{array}{l}\text { Lack of Price Stability } \\
(\log [100+\text { inflation rate }])\end{array}$ & $\begin{array}{c}-6.786^{* * *} \\
(2.412)\end{array}$ & $\begin{array}{c}-6.264^{* *} \\
(2.485)\end{array}$ & $\begin{array}{c}-11.119^{* * *} \\
(3.773)\end{array}$ \\
\hline Intercept & $\begin{array}{c}-1.568 \\
(17.131)\end{array}$ & $\begin{array}{c}10.872 \\
(16.023)\end{array}$ & $\begin{array}{c}29.013 \\
(19.256)\end{array}$ \\
\hline No. Countries/No. Observations & $118 / 664$ & $62 / 352$ & $56 / 312$ \\
\hline $\begin{array}{l}\text { Specification tests (p-values) } \\
\text { (a) Hansen Test } \\
\text { (b) Serial Correlation }\end{array}$ & 0.121 & 0.448 & 0.314 \\
\hline $\begin{array}{l}\text { First-order } \\
\text { Second-order }\end{array}$ & $\begin{array}{l}0.000 \\
0.199\end{array}$ & $\begin{array}{l}0.000 \\
0.252\end{array}$ & $\begin{array}{l}0.003 \\
0.674\end{array}$ \\
\hline $\begin{array}{l}\text { Impact on real GDP per capita growth } \\
\text { CTOT Growth } \\
\text { CTOT Volatility }\end{array}$ & - & $\begin{array}{c}0.485 \\
-0.421\end{array}$ & - \\
\hline
\end{tabular}

Notes: The estimation method is two-step system GMM with Windmeijer (2005) small sample robust correction. Time and fixed effects are included in all the regressions. Regression [1.1] is for the full sample, [1.2] is for primary commodity exporters only, and [1.3] is for the other 56 countries. Standard errors are presented below the corresponding coefficients in brackets. Symbols $* * *, * *$, and $*$ denote significance at $1 \%, 5 \%$, and at $10 \%$ respectively. The dependent variable is the growth rate of real GDP per capita. The impact on GDP per capita growth is calculated as the percentage point impact of a one standard deviation change in the CTOT variable on GDP growth rates. Source: Authors' estimations. 


\section{Table 4: Volatility and the Sources of Growth I}

Unit of Observation, Period:

Volatility Measure:
Non-overlapping five-year averages, 1970 - 2005.

Five year standard deviation of annual CTOT growth.

\begin{tabular}{|c|c|c|c|}
\hline & \\
\hline & {$[2.1]$} & {$[2.2]$} & {$[2.3]$} \\
\hline Initial TFP, in logs & $\begin{array}{l}-4.221^{* * *} \\
(0.990)\end{array}$ & - & - \\
\hline Initial Physical Capital Stock, in logs & - & $\begin{array}{l}-0.601 \\
(1.020)\end{array}$ & - \\
\hline Initial Human Capital Stock, in logs & - & - & $\begin{array}{l}-0.999 \\
(0.750)\end{array}$ \\
\hline Commodity Terms of Trade Growth & $\begin{array}{c}0.113 \\
(0.162)\end{array}$ & $\begin{array}{c}0.186^{* *} \\
(0.093)\end{array}$ & $\begin{array}{c}0.048 \\
(0.030)\end{array}$ \\
\hline Commodity Terms of Trade Volatility & $\begin{array}{c}0.006 \\
(0.102)\end{array}$ & $\begin{array}{c}-0.181^{* *} \\
(0.087)\end{array}$ & $\begin{array}{c}-0.051^{*} \\
(0.029)\end{array}$ \\
\hline Export Sophistication Measure, in logs & $\begin{array}{c}4.130^{* * *} \\
(1.382)\end{array}$ & $\begin{array}{c}4.979^{* * *} \\
(1.700)\end{array}$ & $\begin{array}{l}-0.283 \\
(0.465)\end{array}$ \\
\hline $\begin{array}{l}\text { Control variables } \\
\text { Education } \\
\text { (secondary enrollment, in logs) }\end{array}$ & $\begin{array}{l}1.837^{*} \\
(1.034)\end{array}$ & $\begin{array}{l}-1.417 \\
(1.145)\end{array}$ & $\begin{array}{c}0.643^{* * *} \\
(0.202)\end{array}$ \\
\hline $\begin{array}{l}\text { Trade Openness } \\
\text { (trade volume/GDP, in logs) }\end{array}$ & $\begin{array}{c}2.106 \\
(1.485)\end{array}$ & $\begin{array}{c}3.205^{* *} \\
(1.521)\end{array}$ & $\begin{array}{c}0.442 \\
(0.340)\end{array}$ \\
\hline $\begin{array}{l}\text { Government Burden } \\
\text { (government consumption/GDP, in logs) }\end{array}$ & $\begin{array}{l}-2.669 \\
(2.334)\end{array}$ & $\begin{array}{l}-1.160 \\
(1.714)\end{array}$ & $\begin{array}{c}0.643 \\
(0.427)\end{array}$ \\
\hline $\begin{array}{l}\text { Lack of Price Stability } \\
(\log [100+\text { inflation rate }])\end{array}$ & $\begin{array}{l}-5.019^{*} \\
(2.897)\end{array}$ & $\begin{array}{l}-4.143 \\
(3.375)\end{array}$ & $\begin{array}{l}-0.098 \\
(0.445)\end{array}$ \\
\hline Intercept & $\begin{array}{c}18.689 \\
(19.463)\end{array}$ & $\begin{array}{l}-18.890 \\
(22.793)\end{array}$ & $\begin{array}{l}-0.533 \\
(4.125)\end{array}$ \\
\hline No. Countries / No. Observations & $62 / 354$ & $62 / 354$ & $62 / 354$ \\
\hline $\begin{array}{l}\text { Specification tests (p-values) } \\
\text { (a) Hansen Test } \\
\text { (b) Serial Correlation }\end{array}$ & 0.351 & 0.145 & 0.469 \\
\hline First-order & 0.001 & 0.012 & 0.006 \\
\hline Second-order & 0.569 & 0.110 & 0.533 \\
\hline
\end{tabular}

Notes: The estimation method is two-step system GMM with Windmeijer (2005) small sample robust correction. Time and fixed effects are included in all the regressions. Standard errors are presented below the corresponding coefficients in brackets. Symbols $* * *, * *$, and $*$ denote significance at $1 \%, 5 \%$, and at $10 \%$ respectively. The dependent variables are the growth rate of TFP in regression [2.1], physical capital in regression [2.2], and human capital in regression [2.3]. Source: Authors' estimations. 


\section{Table 5: Growth Effects of CTOT Volatility II}

Unit of Observation, Period:

Volatility Measure:
Non-overlapping five-year averages, 1970 - 2005. GARCH $(1,1)$

\begin{tabular}{|c|c|c|c|}
\hline & \\
\hline & {$[3.1]$} & {$[3.2]$} & {$[3.3]$} \\
\hline Initial Output per Capita, in logs & $\begin{array}{l}-1.101^{* * *} \\
(0.402)\end{array}$ & $\begin{array}{l}-1.053 \\
(0.659)\end{array}$ & $\begin{array}{l}-1.891^{* * *} \\
(0.492)\end{array}$ \\
\hline Commodity Terms of Trade Growth & $\begin{array}{l}0.250^{* * *} \\
(0.077)\end{array}$ & $\begin{array}{l}0.264^{* * *} \\
(0.061)\end{array}$ & $\begin{array}{l}-0.269 \\
(0.445)\end{array}$ \\
\hline Commodity Terms of Trade Volatility & $\begin{array}{l}-0.215 \\
(0.141)\end{array}$ & $\begin{array}{l}-0.198^{* *} \\
(0.099)\end{array}$ & $\begin{array}{l}-0.531 \\
(0.663)\end{array}$ \\
\hline Export Sophistication Measure, in logs & $\begin{array}{l}4.062^{* *} \\
(1.628)\end{array}$ & $\begin{array}{l}2.744^{*} \\
(1.629)\end{array}$ & $\begin{array}{l}4.945^{* * *} \\
(1.561)\end{array}$ \\
\hline Control variables & & & \\
\hline $\begin{array}{l}\text { Education } \\
\text { (secondary enrollment, in logs) }\end{array}$ & $\begin{array}{l}1.029 \\
(0.736)\end{array}$ & $\begin{array}{l}1.347 \\
(1.029)\end{array}$ & $\begin{array}{l}0.155 \\
(1.517)\end{array}$ \\
\hline $\begin{array}{l}\text { Trade Openness } \\
\text { (trade volume/GDP, in logs) }\end{array}$ & $\begin{array}{l}2.498^{* * *} \\
(0.922)\end{array}$ & $\begin{array}{l}2.603^{* * *} \\
(0.892)\end{array}$ & $\begin{array}{l}1.614^{*} \\
(0.957)\end{array}$ \\
\hline $\begin{array}{l}\text { Government Burden } \\
\text { (government consumption/GDP, in logs) }\end{array}$ & $\begin{array}{l}-2.948^{* * *} \\
(1.096)\end{array}$ & $\begin{array}{l}-3.985^{* * *} \\
(1.193)\end{array}$ & $\begin{array}{l}-0.376 \\
(1.423)\end{array}$ \\
\hline $\begin{array}{l}\text { Lack of Price Stability } \\
(\log [100+\text { inflation rate }])\end{array}$ & $\begin{array}{l}-6.945^{* * *} \\
(2.521)\end{array}$ & $\begin{array}{l}-6.500^{* *} \\
(2.633)\end{array}$ & $\begin{array}{l}-10.520^{* *} \\
(4.091)\end{array}$ \\
\hline Intercept & $\begin{array}{l}3.179 \\
(17.047)\end{array}$ & $\begin{array}{l}13.369 \\
(18.453)\end{array}$ & $\begin{array}{l}18.479 \\
(21.873)\end{array}$ \\
\hline No. Countries/No. Observations & $118 / 664$ & $62 / 352$ & $56 / 312$ \\
\hline $\begin{array}{l}\text { Specification tests (p-values) } \\
\text { (a) Hansen Test } \\
\text { (b) Serial Correlation }\end{array}$ & 0.148 & 0.282 & 0.225 \\
\hline First-order & 0.000 & 0.001 & 0.002 \\
\hline Second-order & 0.340 & 0.435 & 0.853 \\
\hline Impact on real GDP per capita growth & & & \\
\hline CTOT Growth & - & 0.503 & - \\
\hline CTOT Volatility & - & -0.537 & - \\
\hline
\end{tabular}

Notes: The estimation method is two-step system GMM with Windmeijer (2005) small sample robust correction. Time and fixed effects are included in all the regressions. Regression [3.1] is for the full sample, [3.2] is for primary commodity exporters only, and [3.3] is for the other 56 countries. Standard errors are presented below the corresponding coefficients in brackets. Symbols $* * *, * *$, and $*$ denote significance at $1 \%, 5 \%$, and at $10 \%$ respectively. The dependent variable is the growth rate of real GDP per capita. The impact on GDP per capita growth is calculated as the percentage point impact of a one standard deviation change in the CTOT variable on GDP growth rates. Source: Authors' estimations. 


\section{Table 6: Volatility and the Sources of Growth II}

Unit of Observation, Period:

Volatility Measure:
Non-overlapping five-year averages, 1970 - 2005. GARCH $(1,1)$

\begin{tabular}{|c|c|c|c|}
\hline & \\
\hline & {$[4.1]$} & {$[4.2]$} & {$[4.3]$} \\
\hline Initial TFP, in logs & $\begin{array}{l}-4.031^{* * *} \\
(1.182)\end{array}$ & - & - \\
\hline Initial Physical Capital Stock, in logs & - & $\begin{array}{l}-0.552 \\
(0.964)\end{array}$ & - \\
\hline Initial Human Capital Stock, in logs & - & - & $\begin{array}{l}-0.992 \\
(0.697)\end{array}$ \\
\hline Commodity Terms of Trade Growth & $\begin{array}{l}0.104 \\
(0.174)\end{array}$ & $\begin{array}{l}0.250^{*} \\
(0.145)\end{array}$ & $\begin{array}{l}0.024 \\
(0.029)\end{array}$ \\
\hline Commodity Terms of Trade Volatility & $\begin{array}{l}0.071 \\
(0.262)\end{array}$ & $\begin{array}{l}-0.401^{* *} \\
(0.182)\end{array}$ & $\begin{array}{l}-0.026 \\
(0.042)\end{array}$ \\
\hline Export Sophistication Measure, in logs & $\begin{array}{l}3.870^{* *} \\
(1.633)\end{array}$ & $\begin{array}{l}3.863^{* *} \\
(1.915)\end{array}$ & $\begin{array}{l}-0.334 \\
(0.431)\end{array}$ \\
\hline $\begin{array}{l}\text { Control variables } \\
\text { Education } \\
\text { (secondary enrollment, in logs) }\end{array}$ & $\begin{array}{l}1.683 \\
(1.150)\end{array}$ & $\begin{array}{l}-0.975 \\
(1.172)\end{array}$ & $\begin{array}{l}0.660^{* * *} \\
(0.225)\end{array}$ \\
\hline $\begin{array}{l}\text { Trade Openness } \\
\text { (trade volume/GDP, in logs) }\end{array}$ & $\begin{array}{l}2.405 \\
(1.907)\end{array}$ & $\begin{array}{l}3.961^{* * *} \\
(1.400)\end{array}$ & $\begin{array}{l}0.496 \\
(0.388)\end{array}$ \\
\hline $\begin{array}{l}\text { Government Burden } \\
\text { (government consumption/GDP, in logs) }\end{array}$ & $\begin{array}{l}-3.076 \\
(2.500)\end{array}$ & $\begin{array}{l}-1.333 \\
(1.825)\end{array}$ & $\begin{array}{l}0.498 \\
(0.341)\end{array}$ \\
\hline $\begin{array}{l}\text { Lack of Price Stability } \\
(\log [100+\text { inflation rate }])\end{array}$ & $\begin{array}{l}-5.845 \\
(3.729)\end{array}$ & $\begin{array}{l}-5.138 \\
(3.423)\end{array}$ & $\begin{array}{c}-0.153 \\
(0.390)\end{array}$ \\
\hline Intercept & $\begin{array}{l}23.160 \\
(25.121)\end{array}$ & $\begin{array}{l}-8.444 \\
(23.846)\end{array}$ & $\begin{array}{l}0.143 \\
(3.614)\end{array}$ \\
\hline No. Countries / No. Observations & $62 / 354$ & $62 / 354$ & $62 / 354$ \\
\hline $\begin{array}{l}\text { Specification tests (p-values) } \\
\text { (a) Hansen Test } \\
\text { (b) Serial Correlation }\end{array}$ & 0.259 & 0.168 & 0.477 \\
\hline $\begin{array}{l}\text { First-order } \\
\text { Second-order }\end{array}$ & $\begin{array}{l}0.001 \\
0.660\end{array}$ & $\begin{array}{l}0.024 \\
0.127\end{array}$ & $\begin{array}{l}0.014 \\
0.791\end{array}$ \\
\hline
\end{tabular}

Notes: The estimation method is two-step system GMM with Windmeijer (2005) small sample robust correction. Time and fixed effects are included in all the regressions. Standard errors are presented below the corresponding coefficients in brackets. Symbols $* * * * *$, and $*$ denote significance at $1 \%, 5 \%$, and at $10 \%$ respectively. The dependent variables are the growth rate of TFP in regression [4.1], physical capital in regression [4.2], and human capital in regression [4.3]. Source: Authors' estimations. 


\section{Table 7: Growth Effects of CTOT Volatility III}

Unit of Observation, Period:

Volatility Measure:
Annual, 1971 - 2007.

GARCH $(1,1)$

\section{Mean Group $\quad$ Pooled Mean Group}

\begin{tabular}{lcc}
\hline Error Correction Term & $-0.248^{* * *}$ & $-0.131^{* * *}$ \\
& $(0.037)$ & $(0.017)$ \\
Commodity Terms of Trade Growth & 0.011 & $0.003^{*}$ \\
& $(0.133)$ & $(0.002)$ \\
Commodity Terms of Trade Volatility & 0.589 & $-0.034^{* * *}$ \\
& $(0.645)$ & $(0.008)$ \\
Control variables & & $0.249^{* * *}$ \\
Trade Openness & & $(0.023)$ \\
(trade volume/GDP, in logs) & -0.004 & $-0.274^{* * *}$ \\
Government Burden & $(0.464)$ & $(0.027)$ \\
(government consumption/GDP, in logs) & 0.060 & $-0.544^{* * *}$ \\
Lack of Price Stability & $(0.417)$ & $(0.059)$ \\
(log [100 + inflation rate]) & -0.536 & \\
& $(1.033)$ & $52 / 1813$ \\
No. Countries / No. Observations & & {$[\mathrm{p}=0.17]$} \\
Joint Hausman Test & $52 / 1813$ & \\
Impact on real GDP per capita growth & 7.68 & 0.013 \\
CTOT Growth & & -0.095 \\
CTOT Volatility & - & \\
\hline
\end{tabular}

Notes: All estimations include a constant country specific term. Standard errors are presented below the corresponding coefficients in brackets. Symbols $* * * * *$, and $*$ denote significance at $1 \%, 5 \%$, and at $10 \%$ respectively. The dependent variable is the growth rate of real GDP per capita. The Schwarz Bayesian Criterion (SBC) has been used to select the lag orders for each group in which the maximum lag is set to two. The p-value is presented next to the corresponding h-test in square-brackets. The impact on GDP per capita growth is calculated as the percentage point impact of a one standard deviation change in the CTOT variable on GDP growth rates. Source: Authors' estimations. 


\section{Table 8: Volatility and the Sources of Growth III}

Unit of Observation, Period:

Volatility Measure:
Annual, 1971 - 2007.

GARCH $(1,1)$

\begin{tabular}{|c|c|c|c|c|}
\hline & \multirow{2}{*}{\multicolumn{2}{|c|}{$[5.1]$}} & \multirow{2}{*}{\multicolumn{2}{|c|}{$[5.2]$}} \\
\hline & & & & \\
\hline & MG & PMG & MG & PMG \\
\hline Error Correction Term & $\begin{array}{l}-0.376^{* * *} \\
(0.045)\end{array}$ & $\begin{array}{l}-0.279^{* * *} \\
(0.033)\end{array}$ & $\begin{array}{c}-0.136^{* * *} \\
(0.022)\end{array}$ & $\begin{array}{c}-0.075^{* * *} \\
(0.015)\end{array}$ \\
\hline Commodity Terms of Trade Growth & $\begin{array}{c}0.013 \\
(0.033)\end{array}$ & $\begin{array}{c}-0.012^{* * *} \\
(0.003)\end{array}$ & $\begin{array}{c}0.107 \\
(0.129)\end{array}$ & $\begin{array}{c}0.007^{* * *} \\
(0.002)\end{array}$ \\
\hline Commodity Terms of Trade Volatility & $\begin{array}{l}-0.130 \\
(0.197)\end{array}$ & $\begin{array}{c}0.005 \\
(0.007)\end{array}$ & $\begin{array}{l}-0.633 \\
(0.816)\end{array}$ & $\begin{array}{c}-0.018^{* * *} \\
(0.005)\end{array}$ \\
\hline $\begin{array}{l}\text { Control variables } \\
\text { Trade Openness } \\
\text { (trade volume/GDP, in logs) }\end{array}$ & $\begin{array}{l}-0.059 \\
(0.288)\end{array}$ & $\begin{array}{c}0.133^{* * *} \\
(0.031)\end{array}$ & $\begin{array}{c}0.755 \\
(0.486)\end{array}$ & $\begin{array}{c}0.542^{* * *} \\
(0.032)\end{array}$ \\
\hline $\begin{array}{l}\text { Government Burden } \\
\text { (government consumption/GDP, in logs) }\end{array}$ & $\begin{array}{l}-0.362 \\
(0.401)\end{array}$ & $\begin{array}{l}-0.267^{* * *} \\
(0.026)\end{array}$ & $\begin{array}{l}4.279 \\
(3.696)\end{array}$ & $\begin{array}{c}0.135^{* * *} \\
(0.025)\end{array}$ \\
\hline $\begin{array}{l}\text { Lack of Price Stability } \\
(\log [100+\text { inflation rate }])\end{array}$ & $\begin{array}{l}-1.359 \\
(1.984)\end{array}$ & $\begin{array}{l}-0.424^{* * *} \\
(0.058)\end{array}$ & $\begin{array}{l}-5.131^{*} \\
(2.791)\end{array}$ & $\begin{array}{r}-0.047^{*} \\
(0.027)\end{array}$ \\
\hline No. Countries / No. Observations & $52 / 1816$ & $52 / 1816$ & $52 / 1819$ & $52 / 1819$ \\
\hline Joint Hausman Test & 2.31 & $p=0.80$ & 6.43 & $p=0.27$ \\
\hline
\end{tabular}

Notes: All estimations include a constant country specific term. Standard errors are presented below the corresponding coefficients in brackets. Symbols $* * *, * *$, and $*$ denote significance at $1 \%, 5 \%$, and at $10 \%$ respectively. The Schwarz Bayesian Criterion (SBC) has been used to select the lag orders for each group in which the maximum lag is set to two. The p-values are presented next to the corresponding h-tests in square-brackets. The dependent variables are the growth rate of TFP in regression [5.1] and physical capital in regression [5.2]. Source: Authors' estimations. 
Table 9: Comparative Statistics

\begin{tabular}{|c|c|c|c|c|}
\hline & $\begin{array}{c}\text { GDP per capita } \\
\text { Growth }\end{array}$ & $\begin{array}{l}\text { CTOT } \\
\text { Growth }\end{array}$ & $\begin{array}{c}\text { CTOT } \\
\text { Volatility }\end{array}$ & $\begin{array}{l}\text { EXPY } \\
\text { Growth }\end{array}$ \\
\hline All Countries (118) & 1.62 & 0.04 & 2.11 & 1.42 \\
\hline 62 Commodity Exporters & 0.86 & 0.18 & 3.23 & 1.13 \\
\hline 56 Commodity Importers & 2.45 & -0.11 & 0.86 & 1.73 \\
\hline OECD Countries (31) & 2.31 & -0.03 & 0.68 & 1.47 \\
\hline 4 Commodity Exporters & 2.12 & 0.14 & 1.78 & 1.01 \\
\hline 27 Commodity Importers & 2.34 & -0.06 & 0.51 & 1.53 \\
\hline MENA Countries (13) & 1.26 & 0.67 & 4.13 & 1.68 \\
\hline 9 Commodity Exporters & 0.77 & 1.02 & 5.34 & 1.64 \\
\hline 4 Commodity Importers & 2.35 & -0.13 & 1.40 & 1.77 \\
\hline OPEC $(9)$ & 0.48 & 0.96 & 5.43 & 1.29 \\
\hline
\end{tabular}

Notes: All numbers are averages over the period 1970-2007 across countries in each sub-group except the export sophistication measure (EXPY Growth) which is averaged over 1970-2006. MENA stands for the Middle East and North Africa countries and are those countries denoted by ${ }^{3}$ in Table 1, whereas the Organization of the Petroleum Exporting Countries (OPEC) and the Organisation for Economic Co-operation and Development (OECD) countries are denoted by ${ }^{4}$ and ${ }^{5}$ respectively. 